\title{
Ordem, liberdades e estadualização do processo penal na Primeira República (1889-1930): João Mendes de Almeida Júnior processualista
}

\author{
Order, Liberties, and the Federal States Criminal Procedural \\ Law in the First Brazilian Republic (1889-1930): João \\ Mendes de Almeida Júnior, a Procedural Law Scholar
}

\section{Régis João Nodari ${ }^{1}$}

Universidade Federal de Minas Gerais, Belo Horizonte/MG, Brasil nodari.regis@gmail.com https://orcid.org/0000-0002-8989-616X

\begin{abstract}
Resumo: Essa investigação pretende analisar o papel da doutrina processual-penalista brasileira durante o período de maior federalização da história brasileira, ocorrido entre 1889 e 1930, com a declaração da república e a consequente outorga de uma autonomia legislativa no processo penal aos Estados federativos por força do artigo 34, inciso 23 da Constituição da República de 1891. Compreender como a doutrina visualizava esse período, apoiava a federalização, lhe era contrária, apoiava ou rejeitava as reformas processuais penais da época e como compreendia o passado e o presente da legislação processual da época são os objetivos desse trabalho. Pretendo analisar os aspectos mais amplos da doutrina processual penalista brasileira de 1889-1930 através do estudo de um dos mais importantes autores da época, João Mendes de Almeida Júnior e sua compreensão da unidade processual, dos sistemas acusatório, inquisitório e misto e das tradições do liberalismo brasileiro.

Palavras-Chave: História do processo penal; Primeira República; Sistemas Processuais; Federalismo; João Mendes de Almeida Júnior.
\end{abstract}

1 Mestre em Direito pela Universidade Federal do Rio Grande do Sul e doutorando em Direito pela Universidade Federal de Minas Gerais Integrante do Studium Iuris - Grupo de Pesquisa em História da Cultura Jurídica (CNPq/UFMG). 
ABSTRACT: This article analyzes the role of Brazilian doctrine on criminal procedure during the First Brazilian Republic (1889-1930), when legislative autonomy in criminal procedure was granted to the states by force of article 34, clause 23 of the Brazilian Republican Constitution of 1891. How doctrine looked at this period, supported federalization or opposed it, supported or rejected criminal procedural reforms, and how it understood the past and present of procedural legislation of that time are the objectives of this paper. It analyzes the broader aspects of the Brazilian criminal procedural doctrine in the period 1889-1930 via o focus on one of the most important authors of the time, João Mendes de Almeida Júnior, and his understanding of the legal unity of the procedural law, as well as the accusatorial, inquisitorial and mixed systems, and the traditions of Brazilian liberalism.

KEYWORDs: History of criminal procedure; First Brazilian Republic; Procedural law systems; Federalism; João Mendes de Almeida Júnior.

SUMÁRIO: 1. Introdução: ordem, liberdades e estadualização; 2. João Mendes de Almeida Júnior: um jurista acadêmico-político; 3. Os sistemas acusatório e inquisitório; 4. A estadualização do processo como uma "perigosa desintegração do direito nacional"; 5. Considerações Finais: garantias liberais contra a estadualização processual republicana. Referências.

\section{INTRODUÇÃO: ORDEM, LIBERDADES E ESTADUALIZAÇÃO}

A doutrina do processo penal no Brasil imperial (1824-1889) era, regra geral, bastante "prática”. Isso significava que o baricentro da reflexão era, principalmente, como aplicar a lei vigente. O Código de Processo Criminal de 1832 com as suas diversas modificações (principalmente a grande reforma de 1871) constituía, basicamente, a lei vigente ${ }^{2}$. Uma doutrina sobre o processo penal 'brasileiro' porque a legislação era 'brasileira'.

Com a Constituição republicana de 1891, essa homologia básica entre doutrina e legislação é rompida. O seu artigo 34, inciso 23, previa

2 NUNES, Diego. Codificação, recodificação, descodificação? Uma história das dimensões jurídicas da justiça no brasil imperial a partir do código de processo criminal de 1832. Revista da faculdade de direito da UFMG, n. 74, p. 135166, jun. 2019. 
que competiria privativamente ao congresso nacional "legislar sobre o direito civil, commercial e criminal da Republica e o processual da justiça federal". Com esse artigo, o direito penal material permanecia sob o monopólio legislativo da União, que já havia inclusive elaborado e decretado um novo Código Penal em 1890 para substituir o antigo Código Criminal do Império de 1830, e assim, a estrutura do direito penal continuava centralizada ${ }^{3}$. Por outro lado, esse dispositivo constitucional estava também inspirado em ideias federalistas, e abriu o caminho para que o processo fosse "estadualizado" ${ }^{4}$, diferentemente do que ocorreria no caso da Argentina, onde a Constituição de 1860 permitiu o desenvolvimento de códigos penais substanciais por parte das províncias ${ }^{5}$. Não por acaso, multiplicaram-se, ao longo da Primeira República, comentários às leis e códigos processuais que os estados da federação, paulatinamente, trataram de providenciar. O grau de diferenças ou semelhanças dessas leis entre si é uma pergunta que teremos que deixar em suspenso, basta-me sublinhar que o simples fato de a legislação ser estadual já era impulso suficiente para a emersão de obras doutrinárias estaduais de cunho prático.

E a produção de alcance nacional? Ela não desapareceu, e, justamente por isso, é interessante indagá-la de um ponto de vista histórico em um momento em que o contexto institucional-legislativo era de

3 Ver: SONTAG, Ricardo. Unidade Legislativa Penal Brasileira e a Escola Positiva Italiana: Sobre um Debate em Torno do Código Penal de 1890. Revista Justiça \& História. v. 11, p. 89-124, 2011.

4 Sobre a estadualização do processo, ver: SABADELL, Ana Lúcia. Los Problemas del derecho procesal penal único en una federación: la experiencia de Brasil. In: Instituto Nacional de Ciencias Penales; Max-Planck Institut fuer Auslaendisches und Internationales Strafrecht (org.). Hacia la Unificación del Derecho Penal. Logros y desafíos de armonización y homologación en México y en el Mundo. Districto Federal México: Instituto Nacional de Ciencias Penales-INACIPE, 2006, v. 1, p. 585-615; SOUZA, P. K. d. As competências estaduais na construção da república: fundamentos e contexto do código do processo civil e comercial do Rio Grande do Sul (1908). 153 f. Dissertação (mestrado). Ori.: Flores, A. d. J. D. Universidade Federal do Rio Grande do Sul. PPGD, Porto Alegre, BR-RS., 2015.

5 Ver: AGÜERO, A.; ROSSO, M. Codifying the Criminal Law in Argentina: Provincial and National Codification in the Genesis of the First Penal Code. In: MASFERRER, Aniceto (org.). The Western Codification of Criminal Law: a Revision of the Myth of its Predominant French Influence. Cham: Springer, 2018. p. 297-322. 
fragmentação. Como essa doutrina opinava sobre a "estadualização" do processo penal? Uma transformação salutar do direito brasileiro em nome do federalismo? Qual seria o alcance da competência estadual para legislar em matéria processual (já que existiam normas nacionais sobre processo, como é o caso dos dispositivos sobre ação penal do Código Penal de 1890)?

O ensino jurídico também passava por transformações, a começar pela autorização de abertura de novas faculdades de direito para além das duas oficiais - Recife e São Paulo - da época imperial ${ }^{6}$. Entre 1889 e 1930, sabe-se que pelo menos onze faculdades foram criadas. O estudo do processo penal, no período imperial e no início da república, estava vinculado ao processo civil ${ }^{7}$. A partir de 1911, com a reforma Rivadávia, até 1925, com a reforma João Luís Alves, o processo penal tornou-se "independente" da disciplina de processo civil. Todavia, a partir de 1925, o processo penal esteve na dependência de outra disciplina: o direito criminal/penal. Isso nos leva a questionar: qual era o perfil dos autores que escreviam sobre processo penal? Eles costumavam lecionar a respectiva disciplina? Qual era o lugar do processo penal no conjunto da produção bibliográfica deles?

No que diz respeito ao conteúdo dessas obras, nós podemos indagar até que ponto elas estavam engajadas com as exigências de manutenção da ordem ou da garantia das liberdades dos indivíduos. Diferentemente

6 Dentre as mudanças no ensino brasileiro trazidos pela Reforma "Benjamin Constant", especialmente o Decreto n. 1232 de 2 de Janeiro de 1891 autorizou a abertura de novas Faculdades de Direito. Quando fossem fundadas pelos particulares, receberiam a designação de "Faculdades Livres", mas ao submeter-se à avaliação federal, usufruiriam dos mesmos privilégios das Faculdades federais. Cf. Decreto n. 1232 h - de 2 de janeiro de 1891. Approva o regulamento das Instituições de Ensino Juridico, dependentes do Ministerio da Instrucção Publica. Disponível em https://legis.senado.leg.br/norma/391704/publicacao/15722524. Acesso em 25 mar. 2021.

7 Sobre a época do Império, em que a disciplina se chamava "Theoria do processo criminal, civil e comercial", ver: Decreto $\mathrm{n}^{0} 7.247$, de 19 de abril de 1879. Reforma o ensino primario e secundario no municipio da Côrte e o superior em todo o Imperio. Disponível em https://www2.camara.leg.br/ legin/fed/decret/1824-1899/decreto-7247-19-abril-1879-547933-publicacaooriginal-62862-pe.html. Acesso em 25 mar. 2021. Na época republicana, o nome da disciplina passou a ser "Processo criminal, civil e comercial" ver: Decreto n. 1232 h - de 2 de janeiro de 1891, op. cit. 
das reconstruções históricas que esquematizam a história do direito penal e da justiça criminal com base em momentos sucessivos marcados pela ordem ou pela liberdade, a melhor historiografia vem chamando a atenção para o fato de que esse pêndulo é constitutivo da modernidade jurídico-penal ${ }^{8}$. No caso brasileiro, o período da Primeira República é particularmente interessante para a análise desse ponto. Embora seja possível dizer que o tópico do balanceamento entre ordem e liberdades esteja presente desde os primórdios dos discursos e das práticas em torno do processo penal moderno no Brasil imperial, entre o final do século XIX e primeiras décadas do século XX nós já temos um contexto novo. Agora, o embate contra a "tirânica" justiça criminal do Antigo Regime, do “terrível” livro V das Ordenações Filipinas, já era uma memória distante; uma justiça criminal, ao menos em linhas gerais, moderna, já estava instaurada. O desejado equilíbrio entre ordem e liberdades, portanto, nesta nova fase, deveria avaliar um sistema, digamos, liberal-moderno. Os juristas, olhando para trás, não viam somente a justiça do Antigo Regime, que, para a perspectiva moderna, era facilmente classificável como tirânica, pois agora já existia um passado liberal a ser sopesado também: ele seria adequado? Ele era suficientemente ou excessivamente liberal? Esses pontos costumavam ser abordados quando os juristas se posicionavam a respeito da famosa questão dos sistemas processuais: acusatório, inquisitório, "misto".

O plano de pesquisa traçado até aqui, bem se vê, é muito amplo. Para os fins deste artigo, vamos nos concentrar na obra de João Mendes de Almeida Júnior (1856-1923). Eu o escolhi para este ensaio de uma pesquisa mais ampla (que vem sendo levada a cabo na minha pesquisa de doutorado) pelos seguintes motivos: i) ele escreveu obras de alcance nacional, o que torna a fricção delas com o problema da "estadualização" particularmente significativa; ii) as suas obras de processo penal foram

8 SBRICCOLI, Mario. La penalistica civile: Teorie e ideologie del diritto penale nell'Italia unita. In: SBRICCOLI, M. Storia del diritto penale e della giustizia. Milano: Giuffrè Editore, 2009; LACCHÈ, Luigi. Il "canone eclettico": Alla ricerca di uno "strato profundo" della cultura giuridica italiana dell'Ottocento. Quaderni fiorentini per la storia del pensiero giuridico moderno, v. 39, n. 1, p. 153-228, 2010; HALPÉRIN, Jean-Louis. Ambivalences des doctrines pénales modernes. Revue de science criminelle et de droit pénal comparé, $\mathrm{n}$. 1, p. 9-16, 2010. 
amplamente citadas na doutrina da época (e, aparentemente, na jurisprudência também), e assim, era um dos autores mais importantes do período, senão o mais importante; iii) consequentemente, suas posições permitem entender o desenvolvimento da doutrina nacional da Primeira República. Com esse foco, parece-me possível, enfim, contribuir para acrescentar algo à historiografia que vem se ocupando deste personagem ${ }^{9}$ e à história do processo penal brasileiro entre o final do século XIX e primeiras décadas do século $\mathrm{XX}^{10}$.

9 A maior parte da historiografia encontrada sobre João Mendes de Almeida Júnior são notas biográficas, focando especialmente a contribuição do autor à faculdade de São Paulo e ao processo civil. Nesses termos, podemos classificar, por exemplo, as biografias feitas para o centenário de seu nascimento na Revista da Faculdade de Direito de São Paulo em 1956. SANTOS, M. A. João Mendes Júnior, mestre de direito processual civil. Revista da Faculdade de Direito, Universidade de São Paulo, v. 51, p. 98-113, 1956.; BUZAID, Alfredo. João Mendes de Almeida Jr. - aspectos de uma grande vida. Revista da Faculdade de Direito, Universidade de São Paulo, v. 51, p. 73-97, 1956; REZENDE FILHO, Gabriel de. João Mendes Júnior, mestre de processo. Revista da Faculdade de Direito, Universidade de São Paulo, v. 51, p. 9-25, 1956. 2021; REALE, Miguel. Escolástica e praxismo na teoria do direito de João Mendes Júnior. Revista da Faculdade de Direito, Universidade de São Paulo, v. 51, p. 26-72, 1956. O mais recente trabalho acerca de João Mendes de Almeida Júnior menciona especialmente a atuação do autor como ministro do Supremo Tribunal Federal, e sua colaboração para uma teoria acerca da posse da terra indígena no país. Ver: CERQUEIRA, Bruno da Silva Antunes de. A demarcação territorial indígena e o problema do "marco temporal": o Supremo Tribunal Federal e o indigenato do Min. João Mendes de Almeida Júnior (1856-1923). 2016.96 f. Monografia (Graduação) - Faculdade de Ciências Jurídicas e Sociais. Centro Universitário de Brasília, Brasília, 2016. Também analisando mais especificamente as questões da opinião de Almeida Júnior sobre os indígenas, há o trabalho de GIAROLA, Flávio Raimundo. Do "triunfo nos trópicos" ao "fim da civilização": "raça", história e nacionalidade na perspectiva dos intelectuais monarquistas-católicos (1889-1917). Belo Horizonte, 2015. Tese (Doutorado em História), FAFICH, Universidade Federal de Minas Gerais, 2015.

10 A historiografia do processo penal brasileiro é bastante pontual. Sobre as relações entre o processo penal e o sistema federalista, Ana Lúcia Sabadell fez um artigo que trata do período da Primeira República como de uma experiência de federalização do processo penal, mas com elementos que caracterizavam uma forte centralidade na união. Cf. SABADELL, Ana Lúcia, op. cit. José Henrique Pierangelli fez uma análise geral sobre o processo penal brasileiro da Primeira República e das codificações estaduais em um livro sobre a história do processo brasileiro, mas não a enxerga como de muitas 


\section{JoÃo Mendes de Almeida JúnIOR: UM JURISTA ACADÊMICO-POLÍTICO}

João Mendes de Almeida Júnior bacharelou-se em 1877 e doutorou-se em 1880 na Faculdade de Direito de São Paulo. Começou sua carreira jurídica como advogado ${ }^{11}$, junto ao escritório de seu pai, João

mudanças frente à época imperial (PIERANGELLI, José Henrique. Processo Penal: evolução histórica e fontes legislativas. São Paulo: Jalovi. 1983). Em uma perspectiva global das codificações processuais na história Brasileira, Diego Nunes publicou um artigo que trata da codificação estadual como um período de "descodificação" do processo penal em comparação com um passado imperial em que as normas estavam presentes primeiramente no Código de Processo de 1832, e posteriormente foram recodificadas com vista à uma atenuação do liberalismo daquele diploma, ver: NUNES, Diego, op. cit. Marcos Alvarez, Fernando Salla e Luiz Souza, reconhecendo uma mudança maior do que Pierangelli, também escreveram sobre o processo penal republicano, e embora afirmem que havia não negligenciáveis mudanças, expuseram que o período não havia alterado uma estrutura inquisitória do processo penal brasileiro. Ver: ALVAREZ, Marcos César; SALLA, Fernando; SOUZA, Luís Antônio F. A Sociedade e a Lei: O código penal de 1890 e as novas tendências penais na primeira república. Justiça \& História, v. 3, n. 6, p. 1-24, 2003, p. 8 Em análises específicas sobre a codificação nos estados, também há alguns poucos trabalhos. Maria de Freitas analisou a codificação do processo penal em Goiás, ver: FREITAS, E. M. de. Disputas políticas e reação centralizadora em Goiás na Primeira República - 1890 - 1905. OPSIS, v. 12, n. 1, p. 202-222, 2012; também Alfredo Flores e Régis Nodari fizeram uma análise sobre o Código de Processo Penal do Rio Grande do Sul, ver: FLORES, Alfredo de Jesus Dal Molin; NODARI, Régis João. Entrelaçamentos culturais na primeira república: o código de processo penal do estado do Rio Grande do Sul (1898) e suas fontes doutrinárias e legislativas. Revista da Faculdade de Direito da Universidade Federal de Minas Gerais Universidade Federal de Minas Gerais, n. 74, p. 65-96, 2019. Danyelle Galvão fez um trabalho comparativo sobre o interrogatório nas codificações estaduais, em um capítulo de sua dissertação, tecendo, todavia, algumas considerações gerais sobre o processo penal da Primeira República (GALVÃO, Danyelle da Silva. Interrogatório por videoconferência. 2012. Dissertação (Mestrado em Direito Processual) - Faculdade de Direito, Universidade de São Paulo, São Paulo, 2012). Por fim, Gabrielle Stricker do Valle publicou um trabalho sobre a reunificação processual na era Vargas: VALLE, Gabrielle Stricker do. Uma história da cultura jurídica processual penal brasileira (1930-1945) (Dissertação, Mestrado). Orientadora: Clara Maria Roman Borges; coorientador: Luís Fernando Lopes Pereira. Curitiba, 2018.

11 CORREIO PAULISTANO: Órgão Republicano. Edição 10245, 29 de outubro de 1890 . 
Mendes de Almeida ${ }^{12}$, que por sua vez era presidente do Instituto dos Advogados, monarquista e opositor dos republicanos positivistas ${ }^{13}$, e irmão de Candido Mendes de Almeida ${ }^{14}$, senador brasileiro que foi condecorado em Roma pela defesa da Santa Sé na questão religiosa ${ }^{15}$, e fortemente associado ao movimento do catolicismo ultramontano ${ }^{16}{ }^{17}$. Sabe-se que a posição política não passa de pai para filho, porém, alguns fatores apontam a sua posição ligada ao monarquismo: havia bastante proximidade entre João Mendes de Almeida Júnior com seu pai; em 1880, ele foi eleito vereador pelo partido Conservador na cidade de São Paulo ${ }^{18}$; participou das homenagens prestadas ao falecimento do Imperador Dom Pedro II; foi homenageado pelo Centro dos Estudantes Monarquistas de São Paulo. Todos esses elementos levam a concluir que Almeida Júnior também era bastante próximo das ideias monarquistas.

12 Que era monarquista, foi obrigado a ocultar-se durante 1894, em período no qual um de seus filhos, não João Mendes, chegou a ser preso pelos republicanos: cf. ALMEIDA, João Mendes de. O direito e o positivismo: discurso proferido pelo Dr João Mendes de Almeida presidente do Instituto dos Advogados de São Paulo. São Paulo: Typ. da Papelaria Guarany de Maciel, 1895.

13 Em 1895 João Mendes de Almeida, em discurso perante o Instituto de Advogados do Brasil, ao mesmo tempo em que criticava a assunção do país ao positivismo republicano, em seus sentidos de separação e laicização do Estado, criticava a tentativa dos positivistas de separar a legislação de sua história e tradição cristã.

14 Escritor de um importante livro sobre as relações entre o direito civil e o direito eclesiástico, ver: ALBANI, Benedetta; MARTINS, Anna Clara Lehmann. The Governance of the Church written between National and Global Perspectives: The Presence of Congregations of Cardinals in Brazilian Manuals of Ecclesiastical Law (1853-1887). Almanack, v. 1, n. 26, p. 1-78, 2020.

15 ALMEIDA, João Mendes de. Algumas notas genealógicas. Revista do Instituto Histórico e Geográfico de São Paulo, v. 10, 1886, p. 482-487.

16 SANTIROCCHI, Ítalo Domingos. A coragem de ser só: Cândido Mendes de Almeida, o arauto do ultramontanismo no Brasil. Almanack, n. 7, p. 59-80, 2014.

17 Esse era um movimento/perspectiva político-religiosa que defendia a ideia de uma Igreja Católica inteiramente autônoma em relação ao Estado, e que defendia em última instância uma atribuição ao papa das questões espirituais e temporais, e a crítica dos governantes que as infringissem. Ver ALBANI; MARTINS, op. cit., p. 19.

18 O BRAZIL: Folha Diaria (RJ). Edição 494, Domingo, 18 de dezembro de 1891; AUCTORIDADE: Orgam do centro dos Estudantes Monarchistas de São Paulo. S. Paulo, 16 de Agosto de 1896. Ano 1, n. 30. 
Almeida Júnior, assim como sua família, frequentemente viajavam ao exterior ${ }^{19}$. Essas viagens, além das conexões via mercado livreiro, contribuíram para o seu arcabouço teórico, que se utilizava de diversos autores estrangeiros em suas construções teóricas e dogmáticas ${ }^{20}$.

João Mendes de Almeida Júnior não tardaria em ser escolhido como professor substituto da Faculdade de Direito de São Paulo, o que veio a ocorrer em $1891^{21}$, frequentemente lecionando a cadeira de Prática Forense ${ }^{22}$. Posteriormente, ele se tornaria professor catedrático da $1^{\mathrm{a}}$ Cadeira de "Teoria do Processo Civil, Comercial, Criminal e Pratica Forense"23. Essa disciplina passou ao longo da Primeira República por diversas mudanças curriculares. Em 1891, havia duas disciplinas, uma para “Teoria do Processo Civil, Comercial, Criminal" e outra para a "Prática Forense”. A partir de 1901, a disciplina de prática passou a ser lecionada conjuntamente à disciplina de teoria ${ }^{24}$. Assim, permaneceu uma única

19 Já consagrado como autor e professor, há o registro de uma viagem para Europa de João Mendes de Almeida Júnior ver: JORNAL DO BRASIL. Rio de Janeiro, Edição 74, Quarta feira, 15 de Março de 1905. Fernando Mendes de Almeida, seu tio em segundo-grau, era o redator-chefe do Jornal do Brasil, e frequentemente viajava para a Europa - principalmente Portugal, onde tinha parentes - e para os Estados Unidos da América JORNAL DO BRASIL. Rio de Janeiro, Edição 289, Sábado, 16 de Outubro de 1897. Ver também: ALMEIDA, João Mendes de. Algumas notas genealógicas. Revista do Instituto Histórico e Geográfico de São Paulo, v. 10, 1886.p. 487.

20 Almeida Júnior faz várias citações, dentre outros autores, à Francesco Carrara para a teorização da prisão preventiva e a Faustin Helie para a teorização das formas processuais. Alguns autores são usados quase exclusivamente para a crítica, como por exemplo, o positivista Raffaele Garofalo (ALMEIDA JÚNIOR, Joao Mendes de. O processo criminal brazileiro. $3^{\text {a }}$ ed. Rio de Janeiro: Typ. Batista de Souza, 1920.p. 9-10; p. 252; p. 412).

21 CORREIO PAULISTANO: Órgão Republicano. Edição 10363, terça feira, 24 de março de 1891.

22 ALMANAK LAEMMERT: Administrativo, Mercantil e Industrial (RJ). Edição A, Ano 1893, p. 1473.

23 ALMANAK LAEMMERT: Administrativo, Mercantil e Industrial (RJ). Edição A00053, Ano 1896, p. X. João Pereira Monteiro ocupava a $2^{\text {a }}$ Cadeira (ver ALMANAK LAEMMERT: Administrativo, Mercantil e Industrial (RJ). Edição A00055, Ano 1898).

24 MARANHÃO, Metódio. Direito Formulário (Matéria da Cadeira de Pratica do Processo). Revista Acadêmica da Faculdade de Direito do Recife, ano XXVIII, 1920, p. 65-69. 
cadeira até 1911, quando o decreto n. 8662, também conhecido como a Reforma Rivadávia Cunha, promoveu uma reforma do currículo e separou as disciplinas em três: "Theoria do Processo Civil e Commercial"; "Prática do Processo Civil e Commercial"; e "Theoria e Pratica do Processo Criminal" ${ }^{25}$. Almeida Júnior, a partir dessa reforma, passou a exercer a cátedra de processo civil e comercial, mas por pouco tempo, já que entre 1913 e 1915 exerceu o cargo de diretor da Faculdade de Direito de São Paulo ${ }^{26}$.

Almeida Júnior também chegou a ser nomeado em 1901 sócio do Instituto Histórico e Geográfico Brasileiro ${ }^{27}$ e ministro do Supremo Tribunal Federal em $1916^{28}$, por nomeação do presidente Venceslau Brás. Por volta de 1920, Almeida Júnior já havia publicado em torno de vinte obras, a maioria delas em matérias processuais ${ }^{29}$.

25 Decreto $\mathrm{n}^{\circ}$ 8.662, de 5 de Abril de 1911. Approva o regulamento das Faculdades de Direito. Disponível em https://www2.camara.leg.br/legin/ fed/decret/1910-1919/decreto-8662-5-abril-1911-499813-republicacao-101881-pe.html. Acesso em 5 abr. 2021.

26 O EDITOR. Dr. João Mendes de Almeida Júnior. Revista da Faculdade de Direito de São Paulo, v. 22, p. 266-287, 1925, p. 276.

27 JORNAL DO COMÉRCIO. Rio de Janeiro. Edição. 236, Sábado, 24 de Agosto de 1901.

28 HORBACH, Carlos Bastide. Memória jurisprudencial: Ministro Pedro Lessa. - Brasília: Supremo Tribunal Federal, 2007. (Série memória jurisprudencial), p. 68.

29 Conforme consta de sua bibliografia, referenciada pelo próprio autor em ALMEIDA JÚNIOR, João Mendes de. O processo criminal brazileiro. $3^{\text {a }}$ ed. Rio de Janeiro: Typ. Batista de Souza, 1920. Na sua contracapa, lista as seguintes obras: “1 Direito Judiciário Brazileiro. 2 Órgãos da fé publica. 3 As formas da «Praxe Forense». 4 A ideia de Autonomia e a pretendida transição do ensino official. 5 O ensino do Direito. 6 Os indígenas do Brazil, seus direitos individuaes e políticos. 7 Soberania, Autonomia, Federação. 8 O Estado - O fim do Estado- A acção do Estado. 9 Plano de «Reforma Judiciaria», submettido ao Congresso do listado de S. Paulo, em 1912-3 volumes. 10 Analyse da discussão do projecto da «Reforma Judiciaria» do Estado de S. Paulo, na Camara dos Deputados, nas sessões de 1913. 11 Golpes de retrospecto. 12 A celebração da chave da Academia ou Festa Symbolica da attenção. 13 Programma de ensino das cadeiras de Theoria e Pratica do Processo Civil, na Faculdade de Direito de S. Paulo. 14 A Personalidade do listado. 15 As codificações estadoaes das leis do processo. 16 «Climax» ou a Escada do Céo. 17 Uma synopse da Historia da Philosophia. 18 Artigos e articulados. 19 A uniformidade, a simplicidade e a economia do nosso processo. 20 Inquirição de testemunhas. 21 A cura da gagueira”. 
Que tipo de jurista era Almeida Júnior no cenário brasileiro da época? Uma forma de análise da intervenção e contribuição dos juristas à cultura jurídica de uma determinada época pode ser traçada com base em tipos ideais. Com o intuito de pensar em modelos suficientemente articulados para compreender historicamente juristas brasileiros que escreviam sobre processo penal na Primeira República, vou utilizar como tipos ideais ${ }^{30}$ o burocrata, o político e o acadêmico, que correspondem abstratamente aos aspectos de vida da prática forense, da vida pública na política, e da vida universitária. Quase sempre, em suas manifestações históricas, o jurista, mesmo o acadêmico, vai mesclar atividades profissionais e políticas ${ }^{31}$. Almeida Júnior poderia ser classificado como um jurista acadêmico-político. Um burocrata compreende aqueles cuja profissão se perfazia primordialmente em seu labor forense de petições, audiências e representações, ou ainda vinculado a algum órgão administrativo estatal; os acadêmicos são aqueles que se ocupavam principalmente de lecionar ou de outras formas do exercício da docência e da pesquisa; e os políticos seriam aqueles profundamente envolvidos com o exercício de cargos políticos, eletivos ou nomeados. João Mendes de Almeida Júnior, embora também tenha se dedicado em algum momento à advocacia, fez das Arcadas o seu principal locus de trabalho. Com diversas publicações e lecionando a muitas turmas, um dos principais aspectos da sua atuação jurídica é o acadêmico. Contudo, o aspecto político é também inegável. Exerceu o cargo de vereador durante a última década imperial, e, na alvorada de sua vida, tornou a exercer uma função cujo caráter é misto entre a política e a magistratura (burocracia) ${ }^{32}$ : o cargo de ministro do Supremo Tribunal Federal.

30 O tipo ideal é uma ferramenta, uma forma, passível de ser usada para uma análise sociológica, que simplifica características encontradas para possibilitar uma melhor compreensão do fenômeno, não necessariamente tendo uma existência histórica concreta. Ver: WEBER, Max. Economy and society: An outline of interpretive sociology. Berkley: University of California Press, 1978. p. 20

31 BOURDIEU, Pierre. Homo academicus. $1^{\mathrm{a}}$ ed. Buenos Aires: Siglo XXI Editores Argentina, 2008. p. 82-83.

32 Gustavo Castagna Machado, em sua tese doutoral, demonstra como a posição do Supremo Tribunal Federal já detinha um elevado grau de politização na época da Primeira República, e que mesmo algumas posições tidas como 
Quanto à produção literária, mesmo sem fazer uma minuciosa análise bibliométrica, é possível dizer que Almeida Júnior foi o autor brasileiro mais citado dentre os juristas que escreviam sobre o processo criminal na Primeira República. Por vezes, ele era mencionado como autoridade, para sustentar posições semelhantes ${ }^{33}$; outras vezes, para ser contrariado ${ }^{34}$.

“técnicas" continham fortes questões políticas por trás. Ver: MACHADO, Gustavo Castagna. "Os ministros do Supremo Tribunal estão divididos em dois grupos que se digladiam": cultura jurídica e política no Supremo Tribunal Federal (1906-1915). Orientador: Flores, Alfredo de Jesus Dal Molin. Co-orientador: Stolleis, Michael. UFRGS, Porto Alegre, 2016.

33 Sustentando que o interrogatório deveria servir somente como meio de defesa e não de instrução e extorsão de confissões, João Evangelista Fortuna citava João Mendes de Almeida Júnior: “Terminada a inquirição das testemunhas passa-se ao interrogatório do réo, o qual - ao contrario do que pensam muitos e no dizer de João Mendes um verdadeiro acto de defesa e não portanto occasião para a auctoridade extorquir do réo com cavilosas perguntas uma pretensa confissão livre e verdadeira. Na Inglaterra até o juiz neste momento dirige uma exhortação ao réo; que se encontra no Jervis act, e pela qual lhe mostra os perigos das palavras que responder imprudentemente. Coherente com esta ideia o Cod. do Proc., art. 98 limita as perguntas que ao réo é licito fazer" (FORTUNA, João Evangelista Peixoto. Manual de direito processual criminal: contendo uma parte theorico-pratica e outra formularia. Rio de Janeiro: Typ. Bedeschi, 1915, p. 71). Sobre a razão de nomear como Código de Processo Criminal, Fortuna sustentava estar do lado de João Mendes de Almeida Júnior - no projeto do Código do Processo Criminal do Maranhão, ver: VIANNA, Godofredo. Projecto de codigo do processo criminal do estado do Maranhão. Maranhão: Imprensa Oficial, 1917. p. 6.

34 Florêncio Carlos de Abreu e Silva argumentava que o júri não fazia parte das tradições brasileiras, tendo sido "importada" pela constituição brasileira de 1824 uma instituição que era tipicamente inglesa, e não pátria. O autor fazia com isso uma réplica à opinião crítica de João Mendes de Almeida Júnior em que este criticava o código sul-rio-grandense por haver adotado as teorias positivistas e buscado restringir a um ponto irreconhecível a instituição do júri, o que seria, portanto, contrário às tradições brasileiras. "Uma das objecções mais sérias, que se têm levantado contra o novo codigo, foi opposta pelo erudito professor da Faculdade de Direito de São Paulo, dr. João Mendes de Almeida Júnior, na sua excellente obra sobre o processo penal brazileiro. Diz elle que o nosso codigo, contrariando as tradições de nossa raça, veio erigir em preceito legislativo, como in anima vili, as theorias da escola positiva italiana. Mas, data venia, de igual modo perguntamos ao illustre cathedratico, que tradições de nossa raça guardou o codigo de 1832, quando é elle proprio quem escreve que «não só o jury, como quasi todas as outras disposições, como bem observou Pimenta Bueno (nos seus Apontamentos sobre o processo criminal 
A principal obra de Almeida Júnior se chama "Processo Criminal Brasileiro”. Quando foi publicada em 1901, ela pretendia suprir a ausência de um tratado de processo penal, tendo sido inclusive objeto do pagamento de um prêmio pela Câmara dos Deputados ${ }^{35}$. Esse prêmio era dado, nos termos do Código do Ensino de 1900, para os professores que produzissem tratados, memórias ou outros trabalhos científicos relevantes para a época. O prêmio era constituído por uma remuneração ao autor e pela impressão de uma certa quantidade de livros pela União ${ }^{36}$. Desse tipo de tratado, temos, por exemplo, o "Traité de l'instruction criminelle" (1867) de Faustin Helie como uma referência teórica importante para França e Bélgica. No Brasil, nem mesmo o "Apontamentos sobre o processo criminal pelo jury" de Pimenta Bueno ${ }^{37}$, que era seguramente o livro de processo penal mais citado e referenciado até então, e considerado um dos clássicos do processo penal brasileiro ${ }^{38}$, seria um tratado no escopo,

brazileiro), - são derivados da legislação da Inglaterra e da França?” (SILVA, Florencio Carlos de Abreu. Código do Processo Penal do Estado do Rio Grande do Sul: estudo critico e comparativo, com grande copia de notas de jurisprudencia. Porto Alegre: Typographia da Livraria Universal de Carlos Echenique. 1909, p. VIII). Sobre a incomunicabilidade dos presos no projeto do Ceará: CARNEIRO, Abner. Vasconcellos, Leao de. Camara, Olivio Dornellas. Projecto de codigo do processo criminal para o estado do ceara. Fortaleza: S.N., 1919, p. 8. JORNAL DO BRASIL. Edição 348, Sábado, 14 de Dezembro de 1901, p. 2.

"Art. 35. O membro do magisterio que compuzer tratados, compendios e memorias scientificas importantes ácerca de materias ensinadas no estabelecimento, terá direito á impressão do seu trabalho por conta do Governo, si a congregação, em escrutinio secreto e por dous terços dos votos da totalidade dos seus membros, o julgar de utilidade para o ensino, não excedendo, porém, de tres mil exemplares a edição impressa á custa dos cofres publicos. Art. 36. Si a congregação, pelo processo estabelecido no artigo precedente, considerar a obra de merito excepcional ou extraordinaria vantagem para o progresso da sciencia ou para texto do ensino, além da impressão taxada no referido artigo, terá o autor direito a um premio, arbitrado pelo Governo, mediante informação do director, e nunca inferior a 2:000\$ ou superior a 5:000 $\$ 000^{\prime \prime}$ (Decreto $\mathrm{n}^{\circ} 3.890$, de $1^{\circ}$ de janeiro de 1901. Approva o Codigo dos Institutos Officiaes de Ensino Superior e Secundario, dependentes do Ministerio da Justiça e Negocios Interiores. Disponível em https://www2.camara.leg.br/legin/fed/decret/1900-1909/decreto-3890-1-janeiro-1901-521287-publicacaooriginal-1-pe.html. Acesso em 5 mai 2021.

37 BUENO, José Antonio Pimenta. Apontamentos sobre o processo criminal pelo jury. Rio de Janeiro: J. Villeneuve e C, 1849. p. 32.

38 Assim o considerava, por exemplo, Oliveira Vianna, durante o tempo em que foi professor de processo penal na faculdade de Niterói (FARIA, Luiz de 
visão de sistema e teoria que pretendia Almeida Júnior ${ }^{39}$. O livro de Almeida Júnior, nesse contexto, seria único no processo penal brasileiro, e assim era propagandeado pela sua editora, como uma obra de investigação científica e teórica em diversos pontos do processo penal, e utilizável por juízes, advogados e estudantes ${ }^{40}$, de modo que exibia um caráter de tratado, indo além de um mero manual. No prefácio à primeira edição, Almeida Júnior mencionou como possíveis destinatários não só os juristas profissionais e estudantes, mas também os congressistas e estadistas. Seu tratado seria uma obra "patriótica" para a admiração das "tradições liberais” brasileiras, que vinham da monarquia e continuavam na república. Em sua estrutura, Almeida Júnior pretendia uma exposição completa do processo penal brasileiro. Em seu conteúdo, o autor sublinhava como um dos mais importantes princípios do processo determinar que a função do poder judiciário era a garantia dos direitos individuais ${ }^{41}$. Em sua breve introdução, é possível perceber não só o objetivo de produzir uma obra acadêmica: há um interesse de divulgar e manter aquilo que considerava como tradições liberais brasileiras no processo penal brasileiro.

\section{Os SISTEMAS ACUSATÓRIO E INQUISITÓRIO}

Sobre os tópicos basilares do processo penal, João Mendes de Almeida Júnior considerava-se um "liberal”. Os seus posicionamentos político-jurídicos no âmbito processual aparecem com clareza quando dos embates com a chamada Escola Positiva italiana. Perante as soluções

Castro. Oliveira Vianna: de Saquarema à Alameda São Boaventura, 41 - Niterói: o autor, os livros, a obra. Rio de Janeiro: Relume Dumará: Núcleo de Antropologia da Política/UFRJ, 2002, p. 115).

39 Em compensação, a comunidade jurídica brasileira dispunha da primeira tradução do tratado de Franz von Liszt, cuja versão em português tinha sido publicada em 1899 (ESPÍNDOLA DE SENA, Nathália Nogueira; SONTAG, Ricardo. The Brazilian translation of Franz von Liszt's Lehrbuch des deutschen Strafrechts (1899): a history of cultural translation between Brazil and Germany. Max Planck Institute for European Legal History Research Paper Series, n. 2019-17, 2019).

40 GAZETA DE NOTICIAS (RJ). Quinta-feira, 22 de Novembro de 1900, p. 6.

41 ALMEIDA JÚNIOR, João Mendes de. Processo Criminal Brazileiro. $1^{\mathrm{a}} \mathrm{ed}$. Rio de Janeiro: Laemmert- \& C., 1901. v. 1. p. V-VI. 
dadas pela Escola Positiva à questão da prisão preventiva, por exemplo, ele se pronunciava em sentido contrário em nome das "conquistas liberais", entendendo que havia imprecisões na fórmula apresentada por Garofalo, pois o "quase-flagrante" não seria uma espécie de flagrante, e por isso não daria a certeza necessária para impor a ordem de prisã $0^{42}$.

Juntamente com a questão da prisão em flagrante, entendia Almeida Júnior que não seria possível aumentar as possibilidades de prisão preventiva em relação àquelas previstas na legislação processual de 1871. A lei n. 2033 de 1871 e seus decretos regulamentadores, por assim dizer, criaram o instituto e a nomenclatura da prisão preventiva no Brasil, ainda que houvesse algumas figuras parecidas no Código de Processo Criminal de $1832^{43}$. A regra da Constituição da República de

42 Ver: "As outras modificações propostas por GAROFALO não são mais dignas de aceitação. Elle assemelha ao flagrante, posto que reconheça extranhos ao flagrante ou ao quasi flagrante, para o effeito de legitimar a prisão dos mendigos viciosos, dos vadios, dos vagabundos e de outras pessoas perigosas e suspeitas, «quando concorram contra elles sufficientes indícios de terem commettido um crime punível com a reclusão, com a detenção ou com o arresto cujo máximo seja de um anno;» elle, imitando uma deplorável ideia do processo austríaco, autorisa, no caso de tumulto, sedição ou facto delictuoso, a que tenham concorrido muitas pessoas, a prisão de todos os presentes e que não estejam immunes da suspeita decoparticipação. Livre-nos Deus de um tal systema, tão contrario ás tradições de nossa raça que, na Ord. L. I, tit. 65, § 37 , não se admittia, mesmo nos arroidos, prender mais de seis pessoas, ibi «se ao Juiz no arroido parecer que alguns são culpados, poderá prender até seis pessoas». Entre outras razões que, em 1832, eram apresentadas para apressar a approvaçâo do Codigo do Processo, estava a da necessidade de acabar completamente com o arbítrio do Juiz na suspeita das pessoas envolvidas nos arroidos. Garofalo, si pudesse influir na nossa legislação, destruiria uma conquista liberal, fundada exactamente na necessidade de afastar da ideia do flagrante delicto tudo quanto pudesse trazer duvida sobre a pratica do acto por determinado delinquente" (ALMEIDA JÚNIOR, 1920, op. cit, p. 341-342).

43 "Art. 133. Resultando do interrogatorio suspeita contra o conduzido, o Juiz o mandará pôr em custodia em qualquer lugar seguro, que para isso designar; excepto o caso de se poder livrar solto, ou admittir fiança, e elle a dér; e procederá na formação da culpa, observando o que está disposto a este respeito no Capitulo seguinte". "Art. 175. Poderão tambem ser presos sem culpa formada os que forem indiciados em crimes, em que não tem lugar a fiança; porém nestes, e em todos os mais casos, á excepção dos de flagrante delicto, a prisão não pode ser executada, senão por ordem escripta da autoridade legitima". 
$1891^{44}$, muito contrariada pela prática, onde ocorriam muitos abusos de “prisões para averiguações" 45 , era a de que ninguém seria preso antes da culpa formada - e a culpa era formada com a sentença de pronúncia nos delitos que iam ao julgamento pelo tribunal do júri. A reforma feita em 1871, se por um lado criava o instituto da prisão preventiva, por outro, colocava uma restrição à sua utilização: tal prisão só seria aplicável aos casos em que existissem indícios veementes, conveniência e a confissão, prova documental ou duas testemunhas que jurassem o ocorrido. A tendência do direito moderno como conquistas liberais e democráticas, para Almeida Júnior, era a de restringir e não de ampliar esse instituto. Por isso ele criticava todas as tentativas de ampliação e criação de novas hipóteses de decretos prisionais. Sua opinião no tópico foi muito usada pelos processualistas da época, que, ao comentarem as reformas da legislação, costumavam citá-las com base em Almeida Júnior ${ }^{46}$.

44 "Art 72 - A Constituição assegura a brasileiros e a estrangeiros residentes no País a inviolabilidade dos direitos concernentes à liberdade, à segurança individual e à propriedade, nos termos seguintes: $§ 13$ - A exceção do flagrante delito, a prisão não poderá executar-se senão depois de pronúncia do indiciado, salvo os casos determinados em lei, e mediante ordem escrita da autoridade competente.§ 14 - Ninguém poderá ser conservado em prisão sem culpa formada, salvas as exceções especificadas em lei, nem levado à prisão ou nela detido, se prestar fiança idônea nos casos em que a lei a admitir".

45 "O ministro da justiça Cândido de Oliveira, em 3 de Julho de 1889, expediu uma circular aos presidentes de províncias, assim concebida: "Haja V. Ex. de recommendar ás autoridades policiaes e judiciarias dessa província a fiel observância das leis relativas á prisão preventiva, que não deve effectuar-se sinão nos casos terminantemente comprehendidos na legislação vigente, sendo que o actual direito não comporta o abuso, que ainda perdura, de prisões para averiguações policiaes', cumprindo que as mencionadas autoridades tenham muito em vista o que dispõe o Aviso-circular de 2 de Janeiro de 1865 sobre prisões illegaes" (ALMEIDA JÚNIOR, 1920, op. cit., p. 318-319). O destaque em itálico era de João Mendes de Almeida Júnior, o que sugere que ele estaria criticando a persistência desse abuso na prática forense. Também Ruy Barbosa criticava os excessos de poderes da polícia à época, entendendo que "as atribuições da polícia andam na razão inversa dos direitos do indivíduo", e que o judiciário, cuja missão era a de conter a polícia, muitas vezes deixava a polícia praticar abusos sem controlá-la efetivamente (BARBOSA, Rui. Obras Completas. Vol. XXV, 1898. Tomo II, p. 201-206).

46 No original, Almeida Júnior mencionava que havia um movimento de modernização no processo penal de sua época que implicava: "tendencia de abolir completamente o segredo dos interrogatórios e dos depoimentos das 
A opinião de Almeida Júnior acerca dos positivistas estava profundamente vinculada ao problema do sistema acusatório versus inquisitório. Devemos lembrar que essa questão foi uma das principais discussões surgidas no século XIX com a teorização do processo penal, auxiliando ao desenvolvimento do estudo comparado da disciplina, que geralmente associava o termo acusatório ao processo penal anglo-saxônico e o termo inquisitório ao processo europeu continental, em especial do antigo regime ${ }^{47}$. Almeida Júnior, dentre os juristas brasileiros, foi o primeiro a aprofundar o assunto de um ponto de vista teórico em publicações escritas, nem mesmo Pimenta Bueno havia tratado do assunto ${ }^{48}$. Segundo Máximo Langer, a dicotomia do sistema acusatório versus inquisitório pode se prestar a diversos usos ${ }^{49}$. Dentro desses usos, Almeida Júnior se utilizou dos termos para comparar o desenvolvimento de estilos processuais na história para, ao final, elaborar tipos ideais de sistemas ${ }^{50}$.

Citando benefícios e malefícios dos sistemas, o nosso jurista acaba mostrando as limitações de ambos. Quanto ao sistema acusatório, quando faltassem as provas, o juiz ficaria impedido de julgar; quanto ao inquisitório, o segredo das diligências, a fria análise dos autos, e as confissões extraídas por tortura, sem serem contrabalanceadas por discussões públicas e com liberdade da defesa, acabariam por minar a descoberta pela verdade ${ }^{51}$. Ele defendia, portanto, o sistema misto, que seria caracterizado por um procedimento inquisitório na fase de formação

testemunhas, limitar os casos da prisão preventiva e abreviar o tempo da formação da culpa" (SIQUEIRA, Galdino. Curso de processo criminal: com referencia especial a legislação brazileira. $2^{\mathrm{a}}$ ed. rev. e aug. São Paulo: Magalhães, 1930, p. 9. Inocêncio Borges da Rosa, por sua vez se utilizou de Galdino Siqueira, e escreveu as mesmas palavras do professor da Faculdade de Niterói, ver: ROSA, Inocencio Borges da. Manual de teoria e pratica do processo penal. v.1-4. Porto Alegre: Globo, [1922-1928]. p. 24-25.

47 LANGER, Máximo. La larga sombra de las categorías acusatorio-inquisitivo. Revista Brasileira de Direito Processual Penal, v. 1, n. 1, 2015, p. 15

48 A matéria já era, contudo, mencionada nas disciplinas de processo. Ver BARRETO, Tobias. Programma de Theoria e Pratica do Processo. In: BARRETO, Tobias. Estudos de direito: Publicação phóstuma dirigida por Silvio Romero). Rio de Janeiro: Laemmert \& C. Editores proprietarios, 1892. p. 467.

50 ALMEIDA JÚNIOR, 1920, op. cit, p. 244-251.

51 Ibd., p. 249-250. 
da culpa, e acusatório nos atos do processo do julgamento ${ }^{52}$, ainda que com a necessidade de algumas reformas salutares para abolir o segredo dos interrogatórios e depoimentos, bem como para limitar casos de prisão preventiva e abreviação da formação de culpa ${ }^{53}$. Almeida Júnior empregava essa dicotomia para explicar o processo penal brasileiro e suas reformas. Ele criticava, por exemplo, a manutenção de atividades decisórias na polícia judiciária dos estados, elogiando o caminho que o decreto n. 848 de 1890 teria feito para restringir o sistema inquisitório, separando as funções judiciárias das policiais ${ }^{54}$. Ele aprovava, também, a tendência geral do processo brasileiro após 1871 de expurgar os traços do modelo inquisitorial ${ }^{55}$, de modo que o sistema brasileiro teria conseguido se tornar até mais liberal (menos inquisitório) do que o francês ${ }^{56}$, ao vedar, com o Decreto n. 4824 de 22 de novembro de 1871, que os juízes pudessem recusar as perguntas das partes ${ }^{57}$ e com o Decreto n. 3084 de 5 de novembro de 1898 vedar o interrogatório do réu em forma inquisitiva $^{58}$. No Brasil, parte da historiografia entende que o sistema teria ficado no meio do caminho entre o sistema acusatório inglês e o sistema misto francês ${ }^{59}$, uma afirmação que Almeida Júnior confirmaria,

52 "Distinguindo, então, nos dous systemas, sómente as formas salutares, as medidas uteis, os legisladores, aproveitando o concurso das forças reciprocas, constituíram um systema mixto, accomodando os actos do processo da instrucção ás praticas do systema inquisitório e os actos do processo do julgamento ás praticas do processo accusatorio" (Ibd. p. 251) Id., p. 251-252.

54 “140. Decorre destes artigos que na justiça federal não ha policia judiciaria, com o direito de iniciativa do procedimento, nem com qualquer funcção decisória. Aliás, já o Decr. n. 848 de 11 de 'Outubro de 1890, 'tendo revelado o intuito de restringir, tanto quanto possível, o que ainda restava do systema inquisitório e de abolir completamente 'o procedimento ex-officio, não necessitava de agentes policiaes sinão para a prisão, para o corpo de delicto directo, para as buscas e apprehensões e para a fiança provisória” (Ibd., p. 241).

55 Ibd, p. 265.

56 Ibd., p. 269.

57 Ibd., p. 266.

58

Ibd., p. 265.

MELO, Marcos Eugênio Vieira. Neoinquisitorialismo processual penal e a contaminação do julgador com os atos de investigação: a burla interna no processo penal brasileiro como obstáculo ao contraditório. Revista 
mas contemporizava, com o entendimento de que a legislação brasileira era mais liberal que a francesa.

Depois de fazer a defesa do sistema misto, Almeida Júnior mencionava criticamente algumas características gerais do processo positivista ${ }^{60}$, tais como a radical oposição às medidas liberais do processo; a tendência à abolição do júri ${ }^{61}$; a contrariedade ao direito da parte de proceder contra o ofensor, já que a pena seria um direito da sociedade ${ }^{62}$; a ênfase na instrução secreta; a ampliação dos casos de

Brasileira de Direito Processual Penal, Porto Alegre, vol. 6, n. 2, p. 951-992, mai./ago. 2020. p. 957.

“Não devemos terminar esta apreciação, sem referirmo-nos a uma escola que, no fim deste seculo surgiu na Italia, com o intuito de reformar completamente, não só a noção do crime, como as regras relativas á pena, á organisazão judiciaria, á acção e ao processo. Referimo nos á Escola denominada - positivista italiana, a cuja frente, em assumptos de processo, se acham o notável magistrado GAROFALO, o professor de direito penal FERRI e o medico Lombroso. Partindo da preocupação dos factores anthropologicos, physicos e sociaes, que determinam as acções humanas, especialmente da temibilidade do indiciado ou delinquente, a nova escola pretende, não só operar uma reacção contra o espirito liberal dos últimos tempos, como uma reforma radical, destinada a assegurar o successo da doutrina anthropologica" (ALMEIDA JÚNIOR, 1920, op. cit., p. 251-252). Almeida Júnior citava essas características gerais a partir do texto Criminologia de Garofalo, porém se distanciava tanto da versão original italiana, como da tradução portuguesa, o que é um sinal de que não lia a versão original, e tomava os argumentos do positivismo a partir de fontes terceiras, ou fazia paráfrase das citações, mesmo quando destacadas.

61 "Eis os pontos culminantes dessa reforma: $1 .^{\circ}$ Nada de jury, nada mesmo de magistrados juristas: os jurados são, em geral, pessoas incultas, sem antecedentes, nem hábitos que garantam o acerto de seus julgamentos ; os magistrados juristas, ao menos os de hoje, imbuidos das doutrinas espiritualistas. não conhecem os indícios physiologicos e anthropologicos que podem fixar a natureza do delinquente e a pena. O magistrado repressivo deve ter, não um diploma do estudo do direito, mas do estudo de sociologia, physiologia e anthropologia criminal. Os jurados são a guarda nacional do direito; entretanto, «a guarda nacional abolida como uma milicia inútil, não era inoffensiva, ao passo que o jury, além de innutil, e extremamente perigoso», diz GAROFALO" (ibd., p. 251).

62 “2. Relativamente á acção, em caso algum, deve-se deixar á parte o direito exclusivo de proceder contra o delinquente, porque a pena, em caso algum, deixa de ser uma necessidade social, considerado o perigo da reincidência" (Ibd., p. 252). 
prisão preventiva com a redução dos crimes afiançáveis ${ }^{63}$; e a restrição de recursos e formalidades ${ }^{64}$.

Essa crítica de Almeida Júnior ao positivismo criminológico estava diretamente ligada ao contexto das reformas brasileiras. Especialmente no Rio Grande do Sul, a reforma do processo penal havia se aproximado bastante dos objetivos da "Riforma della procedura penale in Italia", de autoria de Garofalo e Carelli - de "tornar mais celere e ao mesmo tempo mais seguro o juizo, circundar de garantias o accusado e não deixar sem protecção a victima do crime" ${ }^{\text {. }}$. Nele, muitas das ideias acerca da restrição do interrogatório e separação entre atos secretos e públicos havia sido traduzida pelos sul-rio-grandenses em seu código de $1898^{66}$, além da ampliação das

63 “3. ${ }^{\circ}$ A instrucção deve ser secreta e escripta, limitando-se a publicidade e a oralidade ao caso de contestação sobre o valor das provas do facto, sobre os antecedentes pessoaes e hereditários do indiciado e seu signaes anthropologicos. Os casos de prisão preventiva devem ser ampliados e os de fiança devem ser restringidos. A ultima phase do processo, a mais importante e decisiva e de interesse capital para o accusado, consistirá no exame anthropologico e na applicação mathematica da eliminação, si o delinquente apresentar os caracteres de um criminoso nato. Si não é um criminoso nato, será um alienado, que deve ser internado em asylos ou manicomios especiaes e entregue ao cuidado e á repressão dos médicos alienistas que os dirige” (Ibd., p. 251-252).

64 "4. ${ }^{\circ}$ Os recursos devem ser restrictos e as jurisdicções superiores devem ser menos rigorosas na exigencia do cumprimento das formalidades" (Ibd., p. 252).

CASTILHOS, Julio Prates de. Exposição de motivos do Projeto de Código do Processo Penal do Rio Grande do Sul. 1897. In: RIO GRANDE DO SUL. Leis, Atos e decretos estaduais de 1898. Porto Alegre: A Federação. 1898. P. 169. A frase em italiano está em GAROFALO, Raffaele; CARELLI, Luigi. Riforma della procedura penale in Italia: Progetto di un nuovo Codice. Torino: Fratelli Bocca Editori, 1889. p. VI.

66 "N'esta parte do projecto uma innovaçao importante exige expressa menção: é a que concerne á divisão da formação da culpa em duas phases distinctas, uma da instrucção secreta, outra da instrucção publica. Esta é a grande reforma que Garofalo e Carelli propoem no projecto de revisão do codigo do processo penal da Italia, pelo qual são modeladas as disposições deste projecto." [...]. E' preciso fugir dos exageros, procurando na harmonia de todos os interesses a unica solução possivel. Esse desideratum parece haver attingido o projecto, porque, si a instrucção secreta é instituida no exclusivo interesse da accusação, a instrucção publica é o campo aberto ao livre exercicio da defesa. «No primeiro período secreto, o juiz instructor recolhe os elementos da instrucção, seja a favor, seja contra o accusado, fora da presença das partes; tudo é deixado ao seu criterio, á sua consciencia, á sua equanimidade 
formas de prisão em flagrante e preventiva ${ }^{67}$. Segundo alguns críticos da época, tudo isso significou uma inflexão autoritária no processo penal, e, nas palavras do monarquista Candido Oliveira, teria resultado em um texto legislativo "servilmente copiado e pessimamente traduzido do italiano, do trabalho de Garofalo e Caselli (sic)" ${ }^{6}$. Por um lado, entre os próprios positivistas da época, já se considerava que a sugestão de Garofalo, feita em 1889 à reforma do código de processo italiano de 1865, era moderada frente a outras propostas positivistas ${ }^{69}$ - afinal, ainda eram mantidas algumas competências do júri e ainda se preservava a querela privada ${ }^{70}$. Por

..... «No nosso systema, por outro lado, o accusado nada tem a temer, pois que no segundo periodo da instrucção elle póde fiscalisar o trabalho do juiz repugnando os actos por este cumpridos, apresentando novas testemunhas e reclamando o confronto destas com as que já foram ouvidas. Do exposto é facil verificar-se a superioridade d'este systema sobre o do codigo actual, que; reduzindo o papel do juiz á função automatica de ouvir a testemunhas que em numero limitado lhe devem ser indicadas pelo auctor, e não permittindo ao réu outra faculdade sinão a de assistir á inquirição, e a de contradictar as testemunhas, nem concede ao juiz a minima liberdade de accão, nem faculta ao réu meios de defender-se eficazmente" (CASTILHOS, op. cit., p. 197-198). Compare-se à citação do original em italiano: "II primo periodo è segreto; il Giudice istruttore raccoglie gli elementi della istruzione sia in favore, sia contro l'imputato, fuori la presenza delle p a rti; tutto è lasciato alla sua mente, alla sua coscienza, alla sua equanimità. Solo per gli atti generici, per quegli atti, che non è possibile ripetere e che sono destinati per ; necessità di cose a restare inalterati nel pubblico dibattimento, ammettiamo la presenza e il controllo delle parti. [...] Col nostro sistema, inoltre, l'imputato non ha nulla a temere, poiché nel secondo periodo della istruzione egli può controllare l'opera del giudice, impugnando gli atti da costui compiuti, presentando nuovi testimoni e chiedendone il confronto con quelli già uditi (art. 348 a 350)" (GAROFALO, op. cit, p. CCLII-CCLIII).

67 CASTILHOS, op. cit., p. 190-193.

68 OLIVEIRA, Candido Luis Maria. Justiça. Org: OURO, Affonso Celso de Assis Figueiredo et al. A Decada republicana.. Companhia typographica do Brazil, 1902, p. 49.

69 MILETTI, Marco Nicola. Ritorno all'inquisizione. Scuola positiva e pulsioni autoritarie nel processo penale italiano. Diritto penale XXI secolo, v. 10, p. 455-492, 2011, p. 463-464.

70 Curiosamente, Garofalo expressamente mencionava que não fariam propostas para a abolição do júri, diante de que estavam apenas tentando fazer uma reforma da lei do processo, não sua mudança radical: "Forse riguardando al solo aspetto dell'attitudine dei giudici, noi saremmo stati dall'esperienza indotti a proporre l'abolizione della giurì;tanto questo nostro progetto non ha 
outro lado, é de se argumentar que na média das justificativas e traduções realizadas pelo código gaúcho, eram quase sempre acolhidas as propostas mais radicais dos italianos, sendo que reformas entendidas pelo legislador gaúcho como acusatórias derivavam de outras fontes. Assim, baseando-se na reforma de processo da Bélgica de 1878, o código sul-rio-grandense resolveu nomear o código de Código de Processo Penal ao invés de Processo Criminal, como um passo para eliminar uma "reminescencia do antigo processo inquisitorial"71; e também assim a reforma para abolição da ação ex-officio vinha do próprio Brasil, justificada com base em Pimenta Bueno ${ }^{72}$. Evidentemente, nem todas as reformas propostas pelo código gaúcho eram de inspiração positivista, e especialmente essa última, com a abolição da ação ex-officio, era uma reforma de aspecto acusatório. Nada disso impediu que Almeida Júnior descrevesse o código sul-rio-grandense como um experimento "in anima vili [d]as theorias da Escola positivista italiana", e que por essa razão deveria ser submetido à severa crítica $^{73}$.

Almeida Júnior era, então, um liberal. O problema é que essa qualificação não é suficientemente clara. No sentido do posicionamento político de um modo geral, o nosso jurista poderia ser melhor classificado como um monarquista católico conservador ${ }^{74}$. Em verdade, o catolicismo e o conservadorismo eram até mesmo mais destacados nele do que o monarquismo, já que Almeida Júnior fazia parte da corrente católica ultramontana, e essa corrente inclusive chegou a entrar em embate com

la pretensione di essere tradotto in legge dello Stato, ma è solo la espressione dei nostri voti di riforma" (GAROFALO, op. cit., p. XV).

CASTILHOS, op. cit., p. 170-171.

CASTILHOS, op. cit., p. 175.

73 "A nossa legislação, pois, tem estado isenta de toda a censura neste ponto, a não ser, por occasião de ser agitada em alguns Estados, principalmente no Estado do Rio Grande do Sul, a ideia de experimentar, como in anima vili as theorias da Escola positivista italiana" (ALMEIDA JÚNIOR, 1920, op. cit., p. 339).

74 Esse aspecto do monarquismo e do catolicismo, bem como do conservadorismo, eram bastante pronunciados, como menciona Fábio Giarola (GIAROLA, op. cit, p. 18); Gabriel de Rezende Filho e Miguel Reale vaziam também uma menção particular aos aspectos conservadores de Almeida Júnior, que eram evidentes em sua obra especialmente na visão de uma tradição brasileira, que servia de auxílio à crítica das legislações modernas (FILHO, op. cit., p. 17; REALE, op. cit., p. 67). 
a Coroa brasileira em algumas matérias, em especial, durante a Questão Religiosa (1873-1875) ${ }^{75}$. Liberal também era uma palavra associada, mais genericamente, à modernidade ${ }^{76}$. Assim, na grande maioria das vezes em que Almeida Júnior fazia referências à legislação ou à doutrina de outros países, ele se posicionava frente a tais legislações em termos de liberalismo (mais liberais, ou menos liberais), preferindo, em regra, as soluções mais liberais. Liberal em processo penal, para Almeida Júnior, era aquilo que era contrário ao arbitrário, ao autoritário, como podemos concluir do breve trecho em que ele criticava as propostas de Garofalo para a reforma da legislação do flagrante, no sentido de que aumentavam o arbítrio do juiz e de que seriam contrárias às "tradições de nossa raça” (tradição que, neste caso, teria como marco principal o código de 1832, mas que deitaria raízes, em alguns casos, para além da própria modernidade, chegando às velhas Ordenações Filipinas do século XVII) ${ }^{77}$. Havia, portanto, no fundo dos posicionamentos de Almeida Júnior, uma representação tradicionalista, oriunda da sua formação no pensamento católico tomista, da história do processo penal no Brasil: ser liberal era respeitar as tradições brasileiras. As descontinuidades nessa história seriam meros percalços ${ }^{78}$.

75 Situa como João Mendes de Almeida Júnior como ultramontano Rodrigo Dantas de Medeiros em sua tese sobre a Questão Religiosa (MEDEIROS, Rodrigo Dantas de. Dom Vital: A Questão Religiosa e a Crise Político Institucional no Segundo Reinado. Dissertação (Mestrado em Ciências Sociais - Universidade Estadual Paulista "Júlio de Mesquita Filho", Faculdade de Ciências e Letras (Campus Araraquara). Orientador: Prof. Dr. Carlos Henrique Gileno. 2020. p. 74). Veja-se também que o conflito se deu muito em razão do modelo de relações entre o Estado e a Igreja da época, que configurava um "Estado Confessional". Especialmente a "Questão Religiosa” eclodiu por conta de algumas intervenções do Estado na Igreja Católica que foram consideradas por muitos bispos como violadoras da autonomia da Igreja (SANTIROCCHI, Ítalo Domingos. O paradigma tridentino e a Igreja Católica no Brasil oitocentista: modernidade e secularização. Reflexão, v. 42, n. 2, p. 161-181, 2018., p. 177179). Alfredo Buzaid também destaca o papel do catolicismo e da corrente ultramontana em João Mendes de Almeida Júnior (BUZAID, op. cit., p. 75-77).

76 LYNCH, Christian Edward Cyril. Liberalismo. In: SEBASTIÁN, Javier Fernández (org.). Diccionario político y social del mundo iberoamericano, Madrid: Centro de Estudios Políticos y Constitucionales, 2009, p. 744-751.

77 Ibd., p. 341-342.

78 “em relação ao processo criminal, somos um povo educado sob o regimen de fôrmas liberaes, desde o Codigo do Processo de 1832, revogando o Livro V das Ordenações Philippinas, aliás já depois de abolidas as devassas 


\section{A estadualização do processo como uma "perigosa DESINTEGRAÇÃO DO DIREITO NACIONAL"}

Sobre a questão das competências estaduais no direito processual, João Mendes de Almeida Júnior entendia que os estados somente poderiam legislar na mais estrita e indispensável matéria de organização judiciária, negando, portanto, a possibilidade de legislar no direito processual ${ }^{79}$. Ele pretendia que os estados não pudessem se afastar dos princípios constitucionais da União, especialmente no que tangia à matéria processual, extensamente positivada tanto na constituição como nas leis federais. É possível compreender que o nosso jurista se posicionasse criticamente

; posteriormente, contemplamos a reacção conservadora, que produziu a Lei de 3 de Dezembro de 1841, a qual, comquanto tivesse conferido á policia attribuições judiciarias, não deixou de manter, com accidentaes e uteis modificações, as mesmas fôrmas liberaes do processo, sendo que até desenvolveu os recursos; contemplamos a reacção conciliadora, que pouco a pouco se foi accentuando, até se manifestar no systema da Lei n. 2.033 de 20 de Setembro de 1871, retirando da policia attribuições judiciarias, para, naquillo que passa da sua funcção de vigilância e guarda, convertel-a em simples auxiliar da justiça; contemplamos, finalmente, o Codigo Penal da Republica, firmando-se sobre o principio da inadmissibilidade de punição por facto que «anteriormente» não tenha sido qualificado crime e abolindo quasi completamente o procedimento «ex-officio»" (ALMEIDA JÚNIOR, João Mendes de. A uniformidade, a simplicidade e a economia do nosso processo forense. Revista da Faculdade de Direito de São Paulo, v. 20, p. 123178, 1912. p. 135).

79 Essa posição, sustentada pela primeira vez quando travou a discussão sobre a questão das competências estaduais contra Pedro Lessa (ALMEIDA JÚNIOR, João Mendes de. A nova phase da doutrina e das leis do processo brasileiro. Revista da Faculdade de Direito de São Paulo, v. 7, p.101-126; p. 153-183, 1899; LESSA, Pedro Augusto Carneiro. Da competencia do Estado para legislar sobre o processo das justiças locaes. Revista da Faculdade de Direito de São Paulo, v. 7, p. 127-152, 1899) na Revista da Faculdade de Direito de São Paulo, foi mantida em seu livro Processo Criminal Brasileiro: "Os Estados, em geral, mantiveram, com poucas variantes, a organisação judiciaria e policial e o processo do tempo do Império. Aliás, por maior que seja a sua autonomia, não se podem afastar dos principios constitucionaes da União, tanto no que diz respeito á organisação judiciaria, como no tocante ao processo de acção penal, cuja formas estão subordinadas aos princípios reguladores dos direitos de accusação e de defesa, determinados no art. 407 do Codigo Penal da Republica (Decr. n. 847 de 11. de Outubro de 1890) e em outras leis federaes. (ALMEIDA JUNIOR, 1920, op. cit,, p. 241-242). 
frente às reformas estaduais das legislações processuais penais ${ }^{80}$, pois ele entendia que o processo penal ainda estava regulado de um modo bastante amplo na legislação federal.

Precisamente na questão da ação penal, o Código Penal de 1890 havia legislado em seu artigo 407 acerca das ocasiões em que caberia ação penal pública por iniciativa do promotor e onde caberia ação penal privada por iniciativa do particular. A ação penal na república tinha ganhado um novo paradigma. A regra até então era a de que os crimes seriam de ação penal privada quando não houvesse disposições em contrário, o que fez com que no Império, a ação penal pública, ocorrer somente nos crimes em flagrante, inafiançáveis, públicos e policiais, todos os demais sendo de iniciativa particular ${ }^{81}$. Arley Fernandes Teixeira, em artigo sobre a história do perdão no processo brasileiro ${ }^{82}$, comparou como essa questão estava vinculada à evolução do direito penal moderno no Brasil e à redução dos espaços da justiça negocial frente à justiça hegemônica de aparato. Durante o Império, a regra eram crimes de ação particular, nos quais se permitia o perdão do ofendido e com isso havia um espaço de negociação extraprocessual para resolução dos conflitos fora da justiça estatal. Agora, durante a república, o Código Penal de 1890 reduziria a oito os crimes em que somente se procederia mediante queixa do indivíduo, e portanto, um reduzido espaço para a negociação e perdão do ofendido. As definições sobre a ação penal, portanto, assumiam nesse aspecto um caráter de turning point da história do direito processual penal, de mudança de uma justiça negociada para uma justiça hegemônica, a qual, segundo Mario Sbriccoli, se dava no sentido da fuga dos mecanismos de vingança em prol da resolução dos conflitos por meios estatais ${ }^{83}$. Almeida Júnior,

80 Ver ALMEIDA JÚNIOR, 1920, op. cit, p. 384-385, para uma crítica da jurisprudência do Supremo e da legislação do Distrito Federal.

81 GARRO, Lucas Ribeiro. Furto de gado, ação penal e justiça não estatal: sobre o Nascimento da Ação Penal Pública Condicionada à Representação no Brasil (1860-1899). Revista Brasileira de Direito Processual Penal, v. 5, n. 2, p. 1107-1142, 2019.

82 TEIXEIRA, Arley Fernandes. O perdão do ofendido na cultura jurídico-penal brasileira do século XIX: negociação no século da justiça pública? Revista Brasileira de Direito Processual Penal, v. 5, n. 1, p. 299-338, 2019.

83 SBRICCOLI, Mario.Giustizia Criminale. In: SBRICCOLI, M. Storia del diritto penale e della giustizia. Milano: Giuffrè Editore, 2009. p. 3. 
na linha das teorias da época, entendia que a tendência era de substituição da ação privada pela ação por parte do ministério público como uma maneira de substituir a pena-vendetta pela pena como repressão, e por consequência, a negação do "direito de vingança" ${ }^{44}$. Por outro lado, Almeida Júnior reconhecia que as exceções que ainda previam a ação penal privada seriam casos em que o interesse particular se sobrepunha ao interesse público ${ }^{85}$.

Contudo, ele reconhecia também que o assunto era importante demais para permanecer no domínio legislativo estadual. Almeida Júnior advogava por uma espécie de unidade do direito. Sustentava que somente o congresso poderia legislar sobre matéria processual, em razão especialmente de que a redação do texto constitucional não vedava ao parlamento de enveredar no direito processual, assim, os estados teriam a obrigação de respeitar os princípios constitucionais da União. Especialmente, os estados não poderiam legislar sobre atos decisórios, mas somente sobre atos ordinatórios do processo quando não houvesse lei federal adaptando-os às suas condições particulares. A ação, como ato de necessidade essencial do processo, teria um cariz de direito substancial, constituindo parte do sistema geral do processo criminal, e, assim, do direito de defesa garantido na constituição, que se tornava por isso uma parte da legislação que restaria inalterável por parte dos estados ${ }^{86}$.

Mesmo assim, os estados promoviam muitas alterações no direito processual penal, que eram severamente criticadas por Almeida Júnior. Já no prefácio de seu "Processo Criminal Brasileiro", ele defendia que os estados vinham "fazendo diversas (...) alterações perigosissimas á liberdade e garantia dos indivíduos; e já modificaram a «instituição do Jury», quando a Constituição da Republica quiz e quer mantel-a, tanto na jurisdicção federal, como nas jurisdicções estadoaes, tal como foi constituída no tempo do Império, determinando, claramente, expressamente, terminantemente, no $\S 57$ do art. 72 - «E' mantida a instituição

84 ALMEIDA JÚNIOR, João Mendes de. Processo Criminal Brasileiro. $1^{\mathrm{a}} \mathrm{ed}$. Vol. 2. Rio de Janeiro: Laemmert- \& C, 1901. p. 139-140.

85 ALMEIDA JÚNIOR, 1901, v.2, op. cit., p. 121.

86 ALMEIDA JÚNIOR, João Mendes de. A nova phase da doutrina e das leis do processo brasileiro. Revista da Faculdade de Direito de São Paulo, v. 7, p.101126; p. 153-183, 1899. p. 124-125. 
do jury»" ${ }^{\text {. }}$. Não é de se estranhar, aliás, que Almeida Júnior tenha citado justamente o júri nessa passagem, pois essa instituição era considerada, pelos saudosos do regime monárquico, um importante traço liberal do período do Império ${ }^{88}$. Almeida idealizava o júri justamente a partir dos seus contornos da época imperial. Assim, considerava que era essencial a manutenção do número de jurados em quarenta e oito para o sorteio do conselho, e em doze para o conselho de sentença. Entendia essencial também a manutenção da competência do júri como a instância ordinária para os crimes inafiançáveis ${ }^{89}$.

Esses tópicos, à época, dividiram a doutrina e os codificadores estaduais. Dificilmente havia consenso entre os escritores acerca da constitucionalidade das alterações ao júri, mesmo nesses aspectos que Almeida Junior considerava essenciais ${ }^{90}$. Uma similar divisão ocorreria

87 ALMEIDA JÚNIOR, 1920, v.1, op. cit., p. III e IV.

88 Era o caso dos monarquistas Candido Mendes de Oliveira e que dedicou o sétimo e oitavo capítulos do livro sobre a Justiça da compilação monarquista intitulada "A Década Republicana". Lamentava-se daquilo que entendiam como uma campanha republicana para esvaziar a competência do tribunal do júri para os magistrados togados (OLIVEIRA, op. cit., p. 75-90).

89 ALMEIDA JÚNIOR, João Mendes de. A reforma do processo. Revista do Supremo Tribunal Federal, n. 30, p. 383-403, jul. 1921, p. 396-398.

90 Entendiam inconstitucionais as alterações no número de jurados, além de Almeida Júnior: Rui Barbosa (BARBOSA, Rui. Posse de direitos pessoais: o júri e a independência da magistratura; [prefácio, revisão e notas de José Gomes B. Câmara]. Rio de Janeiro: Ministério da Educação e Cultura : Fundação Casa de Rui Barbosa, 1976); Evaristo de Moraes (MORAES, Evaristo de. Estudinhos de direito: o jury. Rio de Janeiro: Papelaria Mendes Marques, 1896); Candido da Motta (DA MOTTA, Candido Nazianzeno Nogueira. Discurso pronunciado na Sessão Legislativa de 15 de junho de 1898 sobre o projecto que altera algumas disposições da organisação judiciaria do Estado. Revista da Faculdade de Direito de São Paulo, v. 6, p. 195-277, 1898); Rafael Correia da Silva (DA SILVA, Raphael Corrêa. Conferência sobre o jury. Revista da Faculdade de Direito de São Paulo, v. 13, p. 7-32, 1905); Candido Luiz Maria de Oliveira (op. cit.); Pedro Lessa (LESSA, Pedro. A simplificação do processo diante dos principios philosophicos do Direito. São Paulo: [s.n.], 1910); e Francisco de Paula Lacerda de Almeida (ALMEIDA, Francisco de Paula Lacerda de. De que reformas necessita a actual organização judiciaria brazileira? O Direito: revista mensal de legislação, doutrina e jurisprudência, v. 40, n. 117, p. 30-64, jan./abr. 1912). Os mesmos autores se manifestavam contrários à alteração da competência dos crimes do júri com exceção de Candido da Motta e Rafael da Silva, que se manifestavam pela possibilidade de alteração da competência. Rui Barbosa 
entre os estados: muitos deles realizaram alterações no número dos jurados e na competência, outros tantos estados mantiveram esses números intocados ${ }^{11}$. Em outros tópicos, Almeida Júnior fazia parte da maioria da doutrina, que foi seguida em grande parte pelos estados da época, de que o sigilo das votações do jurado e o direito a algum número de recusações imotivadas eram partes essenciais da instituição do júri brasileira92.

Em carta direcionada ao secretário de justiça de São Paulo, e também divulgada na imprensa, posteriormente publicada em livro avulso

e Pedro Lessa não escreveram sobre a questão da competência- e também Adolfo Cirne (CIRNE, Adolpho. O Jury. Revista Acadêmica da Faculdade de Direito do Recife, v. 28, 1920, p. 99-113.); Melchiades Picanço (PICANÇO, Melchiades. A Instituição do Jury. Archivo Judiciário, v. 10, p. 19) e João Evangelista Peixoto Fortuna (FORTUNA, op. cit.). Eram favoráveis à possibilidade de modificação do número de jurados assim como da competência os juristas Arthur Pinto da Rocha (ROCHA, Arthur Pinto da. Direito Público: Primeiro Jury antigo. In: VIANNA, Manuel Alvaro de Souza Sá (org). Congresso jurídico americano. Inauguraçao- 3 de maio de 1900 encerramento - 20 DE maio de 1900. II volume; dissertações (direito publico). Rio de Janeiro: Imprensa Nacional, 1904, p. 598-599); José Tavares Bastos (BASTOS, Jose Tavares. Jury na republica. Rio de Janeiro, H Garnier, 1909); Enéas Galvão (GALVÃO, Enéas. O jury. O Direito: revista mensal de legislação, doutrina e jurisprudência, v. 39, n. 116, p. 48-84, set./dez., 1911, p.80-81); João Vieira do Araújo (ARAUJO, João Vieira de. O Congresso dos governadores para unificação das leis processuaes: memoria apresentada ao Exm. Sr. Desembargador Sigismundo Antonio Gonçalves pelo Dr. João Vieira de Araujo. Rio de Janeiro: Typ. J. Schimidt, 1905); Godofredo Mendes Vianna; e Eduardo Espíndola. Manifestaram-se acerca da conveniência da redução do número de jurados apenas Carvalho Mourão (MOURÃO, Carvalho. De que reformas necessita a actual organização judiciaria brazileira? Francisco de Paula Lacerda de Almeida (org) [et al.]. O Direito: revista mensal de legislação, doutrina e jurisprudência, v. 40, n. 117, p. 30-64, 1912.); Florêncio de Abreu e Silva (SILVA, 1909, op. cit,); e Inocêncio Borges da Rosa (op. cit.).

91 Mantinham o número de 12 jurados os códigos e consolidações do: Rio de Janeiro (1894), Goiás (1892), Justiça Federal (1898), Amazonas (1901), Consolidação Resende Costa de Minas Gerais (1906), Bahia (1915); além de Alagoas e São Paulo em sua legislação orgânica da justiça. Modificaram para reduzir o número de jurados os seguintes estados: Rio Grande do Sul (1898); Pará (1905); Rio de Janeiro (1912); Espirito Santo (1914); Rio Grande do Norte (1918); Piauí (1919); Ceará (1921); Pernambuco (1924); Distrito Federal (1924).

92 BARBOSA, Rui; LESSA, Pedro; SILVA, Raphael Correa da [et al]. Instituição do Jury: Julgamento a Descoberto. O Direito: revista mensal de legislação, doutrina e jurisprudência, v. 73, 1896. 
sobre as codificações estaduais do processo, Almeida Júnior afirmava que os códigos estaduais não se faziam dignos de imitação. Ele criticava os códigos do Amazonas de 1901, do Pará de 1905 e do Rio Grande do Sul de 1898 por não regularem o inquérito policial. Especialmente este último tinha o defeito de atribuir à polícia amplos poderes para requisitar informações e de criar uma fase secreta na formação da culpa. Já o Piauí ia na direção oposta, estabelecendo defesa plena desde o princípio da formação da culpa. Nessa discussão, compreendia que o ideal seria seguir o regime da lei n. 2033 de 1871 e do decreto n. 4824 de 1871, onde o inquérito policial seria um instrumento formalizado dos atos da polícia judiciária ${ }^{93}$. Almeida Júnior reclamava, também, das leis do Distrito Federal, já que teriam abolido a conquista liberal da fiança provisória e alterado as ações sem cuidar do modo de livramento. Além disso, a ampliação da competência dos pretores pelo decreto n. 9263 de 1911 para realizar o processo de sua competência na formação da culpa, tanto para os crimes com livramento solto como para aqueles de livramento afiançado, resultava, na prática, que o réu afiançado poderia se tornar revel às audiências de inquirição sem quebrar a fiança, já que essa só se daria na sentença. E o sujeito sequer poderia ser preso antes da audiência, porque seria prisão sem pronúncia em caso de preventiva, ocorrendo que o Supremo Tribunal Federal frequentemente concedia habeas corpus nessas situações ${ }^{94}$. Outra reforma que entendia inconstitucional era a supressão de prazos do termo de apelação, ou a supressão de recursos que existiam na legislação anterior. Quanto à primeira, o "péssimo exemplo" vinha da legislação federal, a lei n. 848 de 1890. Quanto à segunda, ele se referia expressamente à supressão do protesto por novo júri, instituto consagrado na legislação imperial, e que foi abolido pelo estado do Rio Grande do Sul em $1898^{95}$.

No livro "Direito judiciário" (1918), ele reitera, mas aprofunda essas críticas, reclamando da formação de culpa e pronúncia em crimes de até um ano, da supressão da fiança provisória e da redução a cinco dias da

\footnotetext{
93 ALMEIDA JÚNIOR, João Mendes de. As Codificações Estadoaes das Leis do Processo: cartas abertas ao dr. Herculano de Freitas. [Se][Sn]. p. 31.

94 Ibd., p. 31-32

95 Ibd., p. 32-33.
} 
apelação e do protesto por novo júri no código do Amazonas; e no código do Pará, os problemas seriam, segundo ele, a já mencionada supressão do inquérito, a redução a cinco dias do prazo de apelação, e a manutenção das antigas cauções cominatórias penais de polícia. Ele criticava ainda as incursões dos estados na regulação das condições de exercício das ações ${ }^{96}$.

Assim, a solução, para Almeida Júnior, não seria multiplicar os códigos, mas chegar a um código de processo único comum a todos estados do Brasil para as jurisdições federal e estadual ${ }^{97}$. É um pensamento que o nosso jurista mantém, inclusive, ao opinar sobre as reformas em seu estado, São Paulo, em $1897^{98}$, em $1901^{99}$ e em $1921^{100}$.

96 ALMEIDA JÚNIOR, Joao Mendes de. Direito judiciário brazileiro. $2^{\text {a }}$ ed. Rio de Janeiro: Typ. Baptista de Souza, 1918, p. 382-401.

97

98 SILVA, Raphael Corrêa. Parecer sobre o projecto de reforma da Organisação Judiciaria do Estado de S. Paulo. Revista da Faculdade de Direito de São Paulo, v. 5, p. 261-285, 1897.

Os Estados, para legislar sobre a organisação judicial têm uma faculdade limitada, nos termos do art. 34 da Constituição Federal, pelo respeito aos principios constitucionaes da União. Assim, os Estados podem organisar as justiças locaes $[. .$.$] as garantias constitucionaes da segurança [. .$.$] da execução das$ leis civis, commerciaes e criminaes; ahi está o primeiro limite. E como as leis civis, commerciaes e criminaes só podem ser realisadas por meio da ação, ou voluntária ou contenciosa [...] que a organisação judiciaria terá de acomodar a esta acção, [...] aí está o segundo limite, ou por outra, os Estados não podem legislar, quer sobre o direito de acção, ques sobre o objecto da acção, quer sobre a forma da acção. Não é o processo que se há de acomodar a organizações judiciarias dos Estados, mas é a organisação judiciaria de cada Estado que há de se acomodar ao processo, não só quanto aos actos decisórios, visto que estes affectam a própria relação de direito, como quanto aos actos ordinatórios, visto que estes affectam o direito de acção. Assim é segundo o espirito da própria Constituição Federal, que, mais de uma vez, suppõe principios orgânicos, dos quaes os Estados, certamente, não se podem affastar sem diminuição das garantias constitucionaes da segurança dos direitos: $1^{\circ}$ Não há texto algum conferindo expressamente aos estados a atribuição de legislar sobre o direito processual das justiças locais" (ALMEIDA JÚNIOR, João Mendes de. COELHO, Henrique Jose. MARQUES, Joaquim Roberto de Azevedo. Exposição preliminar das bases para a reforma judiciaria do estado de São Paulo. São Paulo: Espindola, 1901. p. 154-155).

${ }^{100}$ ALMEIDA JÚNIOR, João Mendes de. A reforma do processo. Revista do Supremo Tribunal Federal, n. 30, p. 383-403, jul. 1921, p. 383 


\section{Considerações finaIs: GaRANTIAS LIBERAIS CONTRA A ESTADUALIZAÇÃO PROCESSUAL REPUBLICANA}

Na esteira da forte ideologia da unidade nacional que caracterizou o Estado Novo instaurado em 1937, a fase da estadualização chegaria ao fim com o Código de Processo Penal de $1941^{101}$. Mas a ideia de reunificar o processo não nasceu com a queda da Primeira República. João Mendes de Almeida Júnior, assim como outros autores deste período ${ }^{102}$, tinha uma visão bastante negativa da competência estadual em matéria processual instaurada pela Constituição de 1891. Não por acaso, para além da opinião de lege ferenda, ele propôs interpretações que restringiam o dispositivo constitucional do artigo 34, inciso 23, uma proposta de limitação que era bem maior daquilo que na época o Supremo Tribunal Federal vinha decidindo em sua jurisprudência.

A corte suprema, nas poucas ocasiões em que se manifestou sobre a questão das competências estaduais, limitou-se a estabelecer um veto à legislação estadual que viesse a alterar o art. 407 do Código Penal $^{103}$. Contudo, a ambiguidade de alguns julgados municiou tanto

${ }^{101}$ VALLE, op. cit.

102 Galdino Siqueira compartilhava uma visão muito próxima daquela de Almeida Júnior, que recusava autoridade aos estados de legislarem nos termos gerais do processo penal (SIQUEIRA, op. cit., p. 112). Beviláqua era a favor da reunificação processual, e chegou inclusive a propor que ela fosse realizada mediante acordo entre os Estados, sem passar por uma reforma constitucional (BEVILAQUA, Clovis. Unidade do direito processual. Recife: Imprensa Industrial, 1905).

${ }^{103}$ Esse foi o caso da Revisão Criminal julgada no dia 31 de Março de 1897 contra o Estado de São Paulo. A margem, contudo, foi bastante pequena: oito votos contra cinco. Os votos pela inconstitucionalidade foram de Aquino e Castro, José Hygino, Pindahyba de Mattos; João Pedro, Ribeiro de Almeida, Pereira Franco, Bernardino Ferreira e Figueiredo Júnior. Firmou-se na época a seguinte ementa: "Crime de furto-Acção publica-Lei do Estado- Inconstitucionalidade- Revisão. $1^{\circ}$ Viola o preceito constitucional a lei do Estado que, contra o disposto no art. $407, \S 2^{\circ}$ n. 1 , do Codigo Penal, admitte acção publica no crime de furto. $2^{\circ}$ Nesta hypothese deve ser consultado em revisão o processo instaurado por denuncia do promotor publico". Os votos vencidos, entendendo pela constitucionalidade da legislação processual estadual, eram dos ministros Americo Lobo, H. do Espirito Santo, João Barbalho, Manuel Murlinho, Macedo Soares e Lucio de Mendonça (BRASIL. Justiça Federal. Revisão criminal. Recorrente: Evaristo Silva. Recorrida: A justiça do 
aos que pretendiam uma (re)centralização do direito processual quanto aqueles que defendiam a competência estadual de legislação no processo $^{104}$. Enigmática e emblemática foi a posição assumida pelo Supremo Tribunal Federal no famoso caso do "crime de hermenêutica" acerca do júri sul-rio-grandense. O júri no Rio Grande do Sul fora estatuído com a legislação de organização judiciária em 1895, e previa a redução do número de jurados do conselho de sentença para cinco, a exclusão das recusas imotivadas e o julgamento à descoberto. O juiz de comarca Alcides Lima, entendendo a reforma gaúcha como inconstitucional, ordenou que o júri por ele presidido fosse realizado conforme os moldes da legislação imperial, com base no dispositivo constitucional que indicava a "manutenção da instituição do júri”. Porém, diante desse ato, Alcides Lima foi denunciado e condenado pelo tribunal do Rio Grande do Sul, o que ensejou uma revisão criminal, assinada por Rui Barbosa perante o Supremo Tribunal Federal. A corte suprema absolveu Alcides Lima pelo ato de ter julgado a legislação inconstitucional, mas deixou de apreciar o mérito da constitucionalidade da legislação estadual, assumindo que o juiz poderia ter se equivocado sem com isso ter cometido crime ${ }^{105}$.

Esse caso repercutiu na doutrina da época, que considerou as reformas nas recusas e no julgamento como inconstitucionais, sendo um dos últimos artigos publicados por João Mendes de Almeida Júnior, e certamente ele subscrevia a opinião do pai no assunto ${ }^{106}$. Contudo, Almeida Júnior não testemunhou a volta da centralização do processo penal, pois faleceu em 1923.

A produção literária de João Mendes de Almeida Júnior, em uma parte substancial, refletiu a sua atuação como professor de uma cadeira que

Estado [de São Paulo]. 31 de março de 1897. Gazeta Jurídica. Revista Mensal de Legislação, Doutrina e Jurisprudência do Estado de São Paulo, vol. 15,1897. p. 69-75).

${ }^{104}$ Inocencio Borges da Rosa, por exemplo, faz referência a um julgado da suprema corte que teria entendido como constitucional a legislação do Distrito Federal que alterava legislação processual, ainda que contida no artigo 407 do Código Penal (ROSA, op. cit., p. 58-59).

105 RODRIGUES, Lêda Boechat. História do Supremo Tribunal Federal: Defesa das liberdades civis (1891-1898). Rio de Janeiro: Editôra Civilização Brasileira, 1965, p. 82-85.

106 BARBOSA; LESSA; SILVA [et al], op. cit., p. 8-9. 
conjugava o processo penal com o processo civil. Além dos importantes livros "Processo criminal brasileiro" e "Direito judiciário" (ambos com várias edições), ele escreveu em várias outras ocasiões sobre processo penal e processo civil. No âmbito da sua obra jurídica, a parte processual é a mais importante e numerosa. Todavia, o nosso autor também teve incursões em outras áreas do direito, como é o caso dos seus escritos sobre a condição jurídica dos indígenas ${ }^{107}$, assim como fora do direito, como é o caso dos seus escritos políticos ${ }^{108}$ e filosóficos ${ }^{109}$. O perfil literário de Almeida Júnior não se identifica com o padrão atual de um especialista em processo penal: poucos, hoje em dia, dedicam-se a escrever tanto sobre processo penal quanto sobre processo civil. Por outro lado, já não estamos diante do modelo enciclopédico de jurista bastante típico da época imperial ${ }^{110}$. Resquícios da diversificação na produção literária característica do bacharelismo oitocentista ainda podemos enxergar na produção do nosso autor, porém, o foco do seu engajamento é claro.

A tendência da produção literária de Almeida Júnior - relevância dos escritos sobre processo penal no conjunto da obra e relativa proximidade entre essa produção e a atuação do autor como professor - não deve ser considerada apressadamente, porém, um padrão da época. Um levantamento mais amplo ainda em curso traz vários indícios em sentido contrário ${ }^{111}$.

107 ALMEIDA JÚNIOR, João Mendes de. Os indígenas no Brasil; seus direitos individuais e políticos. São Paulo: Tipografia de Hennier Irmãos, 1912. Sobre esse aspecto do pensamento de Almeida Júnior, ver GIAROLA, op. cit., p. 133 e CERQUEIRA, op. cit., p. 25.

${ }^{108}$ Boa parte deles compilados em 1956: ALMEIDA JÚNIOR, João Mendes de. $O$ século XIX: panorama político. Rio de Janeiro: Freitas Bastos, 1956.

109 Por exemplo, ALMEIDA JÚNIOR, João Mendes de. Uma sinopse da história da filosofia. São Paulo: Tip. Siqueira, 1916.

${ }^{110}$ FONSECA, Ricardo Marcelo. Os juristas e a cultura jurídica brasileira na segunda metade do século XIX. Quaderni fiorentini per la storia del pensiero giuridico moderno, v. 35, n. 1, p. 339-371, 2006; ADORNO. Sérgio. Os aprendizes do poder: O bacharelismo liberal na política brasileira. Rio de Janeiro: Paz e Terra, 1988. p. 158.

${ }^{111}$ Por exemplo José Tavares Bastos e Inocêncio Borges da Rosa, que atuavam como juízes e tiveram uma extensa literatura em processo penal, mas nunca exerceram o magistério, ou mesmo figuras mais aproximadas da política, como Evaristo de Moraes e Rui Barbosa, que tiveram diversos livros e artigos 
A velha retórica do equilíbrio entre exigências de ordem e da garantia das liberdades individuais estava presente. Almeida Júnior não adotava, e inclusive rechaçava, os posicionamentos mais liberticidas presentes tanto na doutrina quanto na legislação da época, como a relativização do princípio da presunção de inocência de um Inocêncio Borges da Rosa $^{112}$ ou a instrução secreta e sem defesa da legislação gaúcha de 1898.

O influxo da chamada Escola Positiva e de uma espécie de "onda criminológica" ${ }^{113}$ desde o final do século XIX vinham colorindo de novos matizes esse problema, especialmente com o discurso da defesa social. Todavia, Almeida Júnior manteve alguma distância em relação a essa onda. Nos seus escritos sobre processo penal, tais ideias apareceram com frequência como exemplos a rechaçar, sempre, no fundo, em nome do que ele considerava o equilíbrio ideal entre ordem e liberdades.

O que os juristas da época consideravam o equilíbrio ideal entre esses dois polos, porém, poderia variar. Almeida Júnior nutria alguma nostalgia pelo período monárquico ${ }^{114}$, o que, de alguma forma, pode ter contribuído para imunizá-lo de uma visão negativa das (limitadas) liberdades conquistadas ao longo do período entre 1824 e 1889 . O uso do binômio ordem e liberdades como categoria historiográfica nos mostra que essa tensão nos conduz a um estrato bastante profundo

publicados, aquele inclusive veio a se tornar bacharel em direito quando sua obra e carreira já estavam bem consolidadas.

${ }^{112}$ ROSA, op. cit., v. 2., p. 21-22. João Mendes de Almeida Júnior incluía a presunção de inocência como uma das características do sistema acusatório (ALMEIDA JÚNIOR, 1920, op. cit., p. 250). Ademais, para Almeida Júnior, a presunção da inocência era uma das principais características do processo brasileiro (ALMEIDA JÚNIOR, 1921, op. cit., p. 398).

${ }^{113}$ Ver DIAS, Rebeca Fernandes. Pensamento Criminológico na Primeira República: O Brasil em defesa da sociedade. 2015. 440 f. Tese (Doutorado em Direito) Programa de Pós-Graduação em Direito da Universidade Federal do Paraná, Curitiba, 2015; SONTAG, Ricardo. Código criminológico? Ciência jurídica e codificação penal no Brasil (1888-1899). Rio de Janeiro: Editora Revan, 2014.

114 "Emfim, cada vez que nos encontramos com uma reforma do processo penal, ouvimos vozes dos tumulos, como vehementes protestos das gerações de 1832, 1841 e 1871. Vem a proposito este clamor de Cícero, no Livro V, «de Republica», I: Que resta, com effeito, dos antigos costumes que faziam a grande republica romana ? Ainda uzamos da palavra - «republica» - , mas, esta, mesma, na realidade, ha muito está perdida.»" (ALMEIDA JUNIOR, 1920, op. cit., p. IV). 
do pensamento jurídico da modernidade, mas que é insuficiente para determinar posicionamentos concretos - tomando o pensamento como statements no sentido de Quentin Skinner ${ }^{115}$ - de juristas. Fez-se necessário, assim, identificar institutos jurídicos em particular e determinar o modo como Almeida Júnior e alguns dos seus contemporâneos se posicionaram comparativamente no específico. Todos falavam em equilíbrio, mas o equilíbrio considerado ideal podia conhecer variações em diversos graus.

Nesse equilíbrio, de um modo geral, Almeida Júnior, se posicionava geralmente de um modo liberal, mas isso não nos deve perder de vista a complexidade do nosso jurista. Assim, no que tangia à prisão preventiva, ao interrogatório como meio de defesa, à manutenção do júri, à não supressão de recursos e à preservação do princípio da presunção de inocência, se colocava com posicionamentos bem mais liberais que as posições extremadas dos comentaristas da legislação gaúcha ${ }^{116}$, ou dos positivistas ${ }^{117}$ que enfatizavam a eficiência da lei e da ordem de modo mais extremado e que, por isso, entendiam, por exemplo, que o júri seria um "germen do crime"118 ou que chegavam até mesmo a subverter o princípio da presunção da inocência. Por outro lado, algumas posições de Almeida Júnior podem ser consideradas menos liberais do que as do positivista Evaristo de Morais - que criticava a legislação e a praxis brasileira na condução dos interrogatórios -, quando Almeida Júnior por exemplo, preferia a solução da lei n. 2033 de 1871, que ainda mantinha o sistema misto na formação da culpa à solução dada pela legislação piauiense de 1911 que estabelecia o contraditório desde a formação da culpa. Almeida Júnior não era o mais liberal dos autores, mas seguramente era mais liberal do que a média dos autores da época, e era um representante de importantes críticas doutrinárias à legislação então vigente - reverberando parcialmente o estilo dos penalistas

\footnotetext{
115 SKINNER, Quentin. Meaning and understanding in the history of ideas. In: TULLY, James (ed.). Meaning and context: Quentin Skinner and his critics. Princeton: Princeton University Press, 1988. p. 29-67. p. 33-36.

116 SILVA, op. cit. e ROSA, op. cit.

117 CASTRO, Viveiros. A Nova Escola Penal. Rio de Janeiro: Domingos de Magalhães, 1894; ARAÚJO, op. cit.

118 LEAL, Aurelino. Germens do crime. Bahia: Livraria Magalhães, 1895.
} 
da penalistica civile italiana oitocentista ${ }^{119}$ - críticas que foram sendo substituídas cada vez mais por uma ênfase na aplicação da lei ou da jurisprudência, no âmbito de uma espécie de crise da "perda da autoridade da doutrina" ${ }^{120}$. Evidentemente, esse é um tópico que não cabe tratar nesse artigo, mas que nos permite entender o importante papel da doutrina jurídica na alvorada da Primeira República brasileira, que se apresentava no controle racional do direito ${ }^{121}$ e na construção de um modelo de federalismo e de Estado brasileiro.

\section{REFERÊNCIAS}

ADORNO. Sérgio. Os aprendizes do poder: O bacharelismo liberal na política brasileira. Rio de Janeiro: Paz e Terra, 1988.

AGÜERO, A.; ROSSO, M. Codifying the Criminal Law in Argentina: Provincial and National Codification in the Genesis of the First Penal Code. In: MASFERRER, Aniceto (org.). The Western Codification of Criminal Law: A Revision of the Myth of its Predominant French Influence. Cham: Springer, 2018. p. 297-322.

ALBANI, Benedetta; MARTINS, Anna Clara Lehmann. The Governance of the Church written between National and Global Perspectives: The Presence of Congregations of Cardinals in Brazilian Manuals of Ecclesiastical Law (1853-1887). Almanack, v. 1, n. 26, p. 1-78, 2020.

ALMANAK LAEMMERT: Administrativo, Mercantil e Industrial (RJ). Edição A, Ano 1893.

ALMANAK LAEMMERT: Administrativo, Mercantil e Industrial (RJ). Edição A00053, Ano 1896.

ALMANAK LAEMMERT: Administrativo, Mercantil e Industrial (RJ). Edição A00055, Ano 1898.

ALMEIDA JÚNIOR, Joao Mendes de. Direito judiciário brazileiro. $2^{\mathrm{a}}$ ed. Rio de Janeiro: Typ. Baptista de Souza, 1918.

\footnotetext{
119 SBRICCOLI, La penalistica civile, op. cit., p. 528.

${ }^{120}$ MARTINS-COSTA, Judith. Autoridade e utilidade da doutrina: a construção dos modelos doutrinários. In: MARTINS-COSTA, Judith. Modelos de Direito Privado. São Paulo: Marcial Pons, 2014. p. 9-32. p. 18-22.

${ }^{121}$ SONTAG, 2014, op. cit., p. 32-33.
} 
ALMEIDA JÚNIOR, João Mendes de. Processo Criminal Brasileiro. $1^{\text {a }}$ ed. Rio de Janeiro: Laemmert- \& C, 1901.

ALMEIDA JÚNIOR, Joao Mendes de. O processo criminal brazileiro. $3^{\text {a }}$ ed. Rio de Janeiro: Typ. Batista de Souza, 1920.

ALMEIDA JÚNIOR, João Mendes de. A reforma do processo. Revista do Supremo Tribunal Federal, n. 30, p. 383-403, jul. 1921.

ALMEIDA JÚNIOR, João Mendes de. A uniformidade, a simplicidade e a economia do nosso processo forense. Revista da Faculdade de Direito de São Paulo, v. 20, p. 123-178, 1912.

ALMEIDA JÚNIOR, João Mendes de. COELHO, Henrique Jose. MARQUES, Joaquim Roberto de Azevedo. Exposição preliminar das bases para a reforma judiciaria do estado de São Paulo. São Paulo, Espindola, 1901.

ALMEIDA JÚNIOR, João Mendes de. O século XIX: panorama político. Rio de Janeiro: Freitas Bastos, 1956.

ALMEIDA JÚNIOR, João Mendes de. Os indígenas no Brasil; seus direitos individuais e políticos. São Paulo: Tipografia de Hennier Irmãos, 1912.

ALMEIDA JÚNIOR, João Mendes de. Uma sinopse da história da filosofia. São Paulo: Tip. Siqueira, 1916.

ALMEIDA JÚNIOR, João Mendes de. As Codificações Estadoaes das Leis do Processo: cartas abertas ao dr. Herculano de Freitas. [Se][Sn].

ALMEIDA JÚNIOR, João Mendes de; DOS SANTOS, Brasilio Rodrigues; DA SILVA, Raphael Corrêa. Parecer sobre o projecto de reforma da Organisação Judiciaria do Estado de S. Paulo. Revista da Faculdade de Direito de São Paulo, v. 5, p. 261-285, 1897.

ALMEIDA JÚNIOR, João Mendes de. A nova phase da doutrina e das leis do processo brasileiro. Revista da Faculdade de Direito de São Paulo, v. 7, p.101-126; p. 153-183, 1899. https://doi.org/10.11606/issn.2318-8227.v7i0p101-126; https:// doi.org/10.11606/issn.2318-8227.v7i0p153-183

ALMEIDA, Francisco de Paula Lacerda de. De que reformas necessita a actual organização judiciaria brazileira? O Direito: revista mensal de legislação, doutrina e jurisprudência, v. 40, n. 117, p. 30-64, jan./abr. 1912.

ALMEIDA, João Mendes de. Algumas notas genealógicas. Revista do Instituto Histórico e Geográfico de São Paulo, v. 10, 1886. 
ALMEIDA, João Mendes de. O direito e o positivismo: Discurso proferido pelo $\mathrm{Dr}$ João Mendes de Almeida presidente do Instituto dos Advogados de São Paulo. São Paulo: Typ. da Papelaria Guarany de Maciel, 1895.

ALVAREZ, Marcos César; SALLA, Fernando; SOUZA, Luís Antônio F. A Sociedade e a Lei: O código penal de 1890 e as novas tendências penais na primeira república. Justiça \& História, v. 3, n. 6, p. 1-24, 2003.

ARAUJO, João Vieira de. O Congresso dos governadores para unificação das leis processuaes: memoria apresentada ao Exm. Sr. Desembargador Sigismundo Antonio Gonçalves pelo Dr. João Vieira de Araujo. Rio de Janeiro: Typ. J. Schimidt, 1905.

AUCTORIDADE. Orgam do centro dos Estudantes Monarchistas de São Paulo. S. Paulo, 16 de Agosto de 1896. Ano 1, n. 30.

BARBOSA, Rui. Obras Completas. Vol. XXV, 1898. Tomo II.

BARBOSA, Rui. Posse de direitos pessoais: o júri e a independência da magistratura [prefácio, revisão e notas de José Gomes B. Câmara]. Rio de Janeiro: Ministério da Educação e Cultura: Fundação Casa de Rui Barbosa, 1976.

BARBOSA, Rui; LESSA, Pedro; SILVA, Raphael Correa da. [et al]. Instituição do Jury: Julgamento a Descoberto. O Direito: revista mensal de legislação, doutrina e jurisprudência, T. 73, 1896.

BARRETO, Tobias. Programma de Theoria e Pratica do Processo. In: BARRETO, Tobias. Estudos de direito: publicação phóstuma dirigida por Silvio Romero. Rio de Janeiro: Laemmert \& C. Editores proprietarios, 1892.

BASTOS, Jose Tavares. Jury na republica. Rio de Janeiro, H Garnier, 1909.

BEVILAQUA, Clovis. Unidade do direito processual. Recife: Imprensa Industrial, 1905.

BOURDIEU, Pierre. Homo academicus. $1^{\mathrm{a}}$ ed. Buenos Aires: Siglo XXI Editores Argentina, 2008.

BRASIL. Justiça Federal. Revisão criminal. Recorrente: Evaristo Silva. Recorrida: A justiça do Estado [de São Paulo]. 31 de março de 1897. Gazeta Jurídica. Revista Mensal de Legislação, Doutrina e Jurisprudência do Estado de São Paulo, vol. 15,1897. p. 69-75.

BUENO, José Antonio Pimenta. Apontamentos sobre o processo criminal pelo jury. Rio de Janeiro: J. Villeneuve e C, 1849. 
BUZAID, Alfredo. João Mendes de Almeida Jr. - aspectos de uma grande vida. Revista da Faculdade de Direito, Universidade de São Paulo, v. 51, p. 73-97, 1956. Disponível em: https://www.revistas.usp.br/rfdusp/article/view/66245. Acesso em: 27 abr. 2021.

CARNEIRO, Abner. Vasconcellos, Leao de. Camara, Olivio Dornellas. Projecto de codigo do processo criminal para o estado do ceara. Fortaleza, S.N., 1919.

CASTILHOS, Julio Prates de. Exposição de motivos do Projeto de Código do Processo Penal do Rio Grande do Sul. 1897. In: RIO GRANDE DO SUL. Leis, Atos e decretos estaduais de 1898. Porto Alegre: A Federação, 1898.

CASTRO, Viveiros. A Nova Escola Penal. Rio de Janeiro: Domingos de Magalhães, 1894.

CERQUEIRA, Bruno da Silva Antunes de. A demarcação territorial indígena e o problema do "marco temporal": o Supremo Tribunal Federal e o indigenato do Min. João Mendes de Almeida Júnior (1856-1923). 2016.96 f. Monografia (Graduação) - Faculdade de Ciências Jurídicas e Sociais. Centro Universitário de Brasília, Brasília, 2016.

CIRNE, Adolpho. O Jury. Revista Acadêmica da Faculdade de Direito do Recife, v. 28, p. 99-113, 1920.

CORREIO PAULISTANO: Órgão Repúblicano. Edição 10245, 29 de outubro de 1890.

CORREIO PAULISTANO: Órgão Repúblicano. Edição 10363, terça feira, 24 de março de 1891.

DA MOTTA, Candido Nazianzeno Nogueira. Discurso pronunciado na Sessão Legislativa de 15 de junho de 1898 sobre o projecto que altera algumas disposições da organisação judiciaria do Estado. Revista da Faculdade de Direito de São Paulo, v. 6, p. 195-277, 1898.

DA SILVA, Raphael Corrêa. Conferência sobre o jury. Revista da Faculdade de Direito de São Paulo, v. 13, p. 7-32, 1905.

DIAS, Rebeca Fernandes. Pensamento Criminológico na Primeira República: O Brasil em defesa da sociedade. 2015. 440 f. Tese (Doutorado em Direito) - Programa de Pós-Graduação em Direito da Universidade Federal do Paraná, Curitiba, 2015.

ESPÍNDOLA DE SENA, Nathália Nogueira; SONTAG, Ricardo. The Brazilian translation of Franz von Liszt's Lehrbuch des deutschen Strafrechts (1899): a history of cultural translation between Brazil and Germany. Max Planck Institute for European Legal History Research Paper Series, n. 2019-17, 2019. 
FARIA, Luiz de Castro. Oliveira Vianna: de Saquarema à Alameda São Boaventura, 41 - Niterói: o autor, os livros, a obra. Rio de Janeiro: Relume Dumará: Núcleo de Antropologia da Política/UFRJ, 2002.

FLORES, Alfredo de Jesus Dal Molin; NODARI, Régis João. Entrelaçamentos culturais na primeira república: o código de processo penal do estado do Rio Grande do Sul (1898) e suas fontes doutrinárias e legislativas. Revista da Faculdade de Direito da Universidade Federal de Minas Gerais. n. 74, p. 65-96, 2019. https://doi. org/10.12818/p.0304-2340.2019v74p65

FONSECA, Ricardo Marcelo. Os juristas e a cultura jurídica brasileira na segunda metade do século XIX. Quaderni fiorentini per la storia del pensiero giuridico moderno, v. 35, n. 1, p. 339-371, 2006.

FORTUNA, João Evangelista Peixoto. Manual de direito processual criminal: contendo uma parte theorico-pratica e outra formularia. Rio de Janeiro, RJ: Typ. Bedeschi, 1915.

FREITAS, E. M. de. Disputas políticas e reação centralizadora em Goiás na Primeira República - 1890 - 1905. OPSIS, v. 12, n. 1, p. 202-222, 2012. https://doi. org/10.5216/o.v12i1.18332

GALVÃO, Danyelle da Silva. Interrogatório por videoconferência. 2012. Dissertação (Mestrado em Direito Processual). Faculdade de Direito, Universidade de São Paulo, São Paulo, 2012. https://doi.org/10.11606/d.2.2012.tde-19022013-101210

GALVÃO, Enéas. O jury. O Direito: revista mensal de legislação, doutrina e jurisprudência, v. 39, n. 116, p. 48-84, set./dez., 1911.

GARRO, Lucas Ribeiro. Furto de gado, ação penal e justiça não estatal: sobre o Nascimento da Ação Penal Pública Condicionada à Representação no Brasil (18601899). Revista Brasileira de Direito Processual Penal, v. 5, n. 2, p. 1107-1142, 2019. https://doi.org/10.22197/rbdpp.v5i2.214

GAROFALO, Raffaele; CARELLI, Luigi. Riforma della procedura penale in Italia: Progetto di un nuovo Codice. Torino: Fratelli Bocca Editori, 1889.

GAZETA DE NOTICIAS (RJ) Quinta-feira, 22 de Novembro de 1900. Disponível em http://memoria.bn.br/DocReader/103730_04/1547. Acesso em 3 mai. 2021.

GIAROLA, Flávio Raimundo. Do "triunfo nos trópicos" ao "fim da civilização": "raça", história e nacionalidade na perspectiva dos intelectuais monarquistas-católi$\cos$ (1889-1917). Belo Horizonte, 2015. Tese (Doutorado em História), FAFICH, Universidade Federal de Minas Gerais, 2015. 
HALPÉRIN, Jean-Louis. Ambivalences des doctrines pénales modernes. Revue de science criminelle et de droit pénal comparé, n. 1, p. 9-16, 2010.

HORBACH, Carlos Bastide. Memória jurisprudencial: Ministro Pedro Lessa. Brasília: Supremo Tribunal Federal, 2007. (Série memória jurisprudencial) Disponível em: www.stf.jus.br/arquivo/cms/publicacaoPublicacaoInstitucionalMemoriaJurisprud/ anexo/PedroLessa.pdf Acesso em 5 mai. 2021.

JORNAL DO BRASIL. Rio de Janeiro, Edição 74, Quarta feira, 15 de Março de 1905. JORNAL DO BRASIL. Rio de Janeiro. Edição 348, Sábado, 14 de Dezembro de 1901. JORNAL DO BRASIL. Rio de Janeiro. Edição 289, Sábado, 16 de Outubro de 1897. JORNAL DO COMÉRCIO. Rio de Janeiro. Edição 236, Sábado, 24 de Agosto de 1901. LACCHÈ, Luigi. Il “canone eclettico”. Alla ricerca di uno" strato profundo” della cultura giuridica italiana dell'Ottocento. Quaderni fiorentini per la storia del pensiero giuridico moderno, v. 39, n. 1, p. 153-228, 2010.

LANGER, Máximo. La larga sombra de las categorías acusatorio-inquisitivo. Revista Brasileira de Direito Processual Penal, v. 1, n. 1, 2015. https://doi.org/10.22197/ rbdpp.v1i1.2

LEAL, Aurelino. Germens do crime. Bahia: Livraria Magalhães, 1895.

LESSA, Pedro. A simplificação do processo diante dos principios philosophicos do Direito. São Paulo: [s.n.], 1910. Disponível em http://sistemas.stf.jus.br/xmlui/ handle/123456789/911. Acesso 2 fev. 2021.

LESSA, Pedro Augusto Carneiro. Da competencia do Estado para legislar sobre o processo das justiças locaes. Revista da Faculdade de Direito de São Paulo, v. 7, p. 127-152, 1899. https://doi.org/10.11606/issn.2318-8227.v7i0p127-152

LYNCH, Christian Edward Cyril. Liberalismo. In: SEBASTIÁN, Javier Fernández, (org.). Diccionario político y social del mundo iberoamericano, Madrid: Centro de Estudios Políticos y Constitucionales, 2009.

MACHADO, Gustavo Castagna. "Os ministros do Supremo Tribunal estão divididos em dois grupos que se digladiam”: cultura jurídica e política no Supremo Tribunal Federal (1906-1915). Orientador: Flores, Alfredo de Jesus Dal Molin. Co-orientador: Stolleis, Michael. UFRGS, Porto Alegre, 2016.

MARANHÃO, Metódio. Direito Formulário (Matéria da Cadeira de Pratica do Processo). Revista Acadêmica da Faculdade de Direito do Recife, ano XXVIII, p. 63-79, 1920. 
MARTINS-COSTA, Judith. Autoridade e utilidade da doutrina: a construção dos modelos doutrinários. In: MARTINS-COSTA, Judith. Modelos de Direito Privado. São Paulo: Marcial Pons, 2014. p. 9-32.

MEDEIROS, Rodrigo Dantas de. Dom Vital: A Questão Religiosa e a Crise Político Institucional no Segundo Reinado. Dissertação (Mestrado em Ciências Sociais). Orientador: Prof. Dr. Carlos Henrique Gileno. Universidade Estadual Paulista "Júlio de Mesquita Filho”, Faculdade de Ciências e Letras (Campus Araraquara), 2020.

MELO, Marcos Eugênio Vieira. Neoinquisitorialismo processual penal e a contaminação do julgador com os atos de investigação: a burla interna no processo penal brasileiro como obstáculo ao contraditório. Revista Brasileira de Direito Processual Penal, Porto Alegre, vol. 6, n. 2, p. 951-992, mai./ago. 2020. https:// doi.org/10.22197/rbdpp.v6i2.314

MILETTI, Marco Nicola. Ritorno all'inquisizione. Scuola positiva e pulsioni autoritarie nel processo penale italiano. Diritto penale XXI secolo, v. 10, p. 455-492, 2011.

MORAES, Evaristo de. Estudinhos de direito: o jury. Rio de Janeiro: Papelaria Mendes Marques, 1896.

MOURÃO, Carvalho. De que reformas necessita a actual organização judiciaria brazileira? Francisco de Paula Lacerda de Almeida (org) [et al.]. O Direito: revista mensal de legislação, doutrina e jurisprudência, v. 40, n. 117, p. 30-64, 1912.

NUNES, Diego. Codificação, recodificação, descodificação? Uma história das dimensões jurídicas da justiça no brasil imperial a partir do código de processo criminal de 1832. Revista da faculdade de direito da UFMG, n. 74, p. 135-166, jun. 2019. https://doi.org/10.12818/p.0304-2340.2019v74p135

O BRAZIL: Folha Diaria (RJ). Edição 494, Domingo, 18 de dezembro de 1891.

O EDITOR. Dr. João Mendes de Almeida Júnior. Revista da Faculdade de Direito de São Paulo, v. 22, p. 266-287, 1925. https://doi.org/10.11606/issn.2318-8227. v22i0p267-287

OLIVEIRA, Candido Luis Maria. Justiça. In: FIGUEIREDO, Affonso Celso de Assis et al. A Decada republicana. Companhia typographica do Brazil, 1902.

PICANÇO, Melchiades. A Instituição do Jury. Archivo Judiciário, v. 10, 19.

PIERANGELLI, José Henrique. Processo Penal: evolução histórica e fontes legislativas. São Paulo: Jalovi, 1983.

REALE, Miguel. Escolástica e praxismo na teoria do direito de João Mendes Júnior. Revista da Faculdade de Direito, Universidade de São Paulo, v. 51, p. 26-72, 
1956. Disponível em: https://www.revistas.usp.br/rfdusp/article/view/66244. Acesso em: 27 abr. 2021.

REZENDE FILHO, Gabriel de. João Mendes Júnior, mestre de processo. Revista da Faculdade de Direito, Universidade de São Paulo, v. 51, p. 9-25, 1956. Disponível em: https://www.revistas.usp.br/rfdusp/article/view/66243. Acesso em: 27 abr. 2021.

ROCHA, Arthur Pinto da. Direito Público: Primeiro Jury antigo. In: VIANNA, Manuel Alvaro de Souza Sá (org). Congresso jurídico americano. Inauguração - 3 de maio de 1900 encerramento - 20 de maio de 1900. II volume; dissertações (direito publico). Rio de Janeiro: Imprensa Nacional, 1904. p. 529-599.

RODRIGUES, Lêda Boechat. História do Supremo Tribunal Federal: Defesa das liberdades civis (1891-1898). Rio de Janeiro: Editora Civilização Brasileira, 1965.

ROSA, Inocencio Borges da. Manual de teoria e pratica do processo penal. v.1-4. Porto Alegre: Globo, [1922-1928]. 4 v.

SABADELL, Ana Lúcia. Los Problemas del derecho procesal penal único en una federación: la experiencia de Brasil. In: Instituto Nacional de Ciencias Penales; Max-Planck Institut fuer Auslaendisches und Internationales Strafrecht (org.). Hacia la Unificación del Derecho Penal. Logros y desafíos de armonización y homologación en México y en el Mundo. Districto Federal- México: Instituto Nacional de Ciencias Penales-INACIPE, 2006, v. 1, p. 585-615.

SANTIROCCHI, Ítalo Domingos. A coragem de ser só: Cândido Mendes de Almeida, o arauto do ultramontanismo no Brasil. Almanack, n. 7, p. 59-80, 2014.

SANTIROCHI, Ítalo Domingos. O paradigma tridentino e a Igreja Católica no Brasil oitocentista: modernidade e secularização. Reflexão, v. 42, n. 2, p. 161-181, 2018.

SANTOS, M. A. João Mendes Júnior, mestre de direito processual civil. Revista da Faculdade de Direito, Universidade de São Paulo, v. 51, p. 98-113, 1956. Disponível em: https://www.revistas.usp.br/rfdusp/article/view/66246. Acesso em: 27 abr. 2021.

SBRICCOLI, Mario. Giustizia Criminale. In: SBRICCOLI, M. Storia del diritto penale e della giustizia. Milano: Giuffrè Editore, 2009. p. 3-44.

SBRICCOLI, Mario. La penalistica civile: Teorie e ideologie del diritto penale nell'Italia unita. In: SBRICCOLI, M. Storia del diritto penale e della giustizia. Milano: Giuffrè Editore, 2009. 
SILVA, Florencio Carlos de Abreu. Código do Processo Penal do Estado do Rio Grande do Sul: estudo critico e comparativo, com grande copia de notas de jurisprudencia. Porto Alegre: Typ. Liv. Universal, 1909.

SIQUEIRA, Galdino. Curso de processo criminal: com referencia especial a legislação brazileira. $2^{\text {a }}$ ed. rev. e aug. São Paulo: Magalhães, 1930.

SKINNER, Quentin. Meaning and understanding in the history of ideas. In: TULLY, James (ed.). Meaning and context: Quentin Skinner and his critics. Princeton: Princeton University Press, 1988. p. 29-67.

SONTAG, Ricardo. Unidade Legislativa Penal Brasileira e a Escola Positiva Italiana: Sobre um Debate em Torno do Código Penal de 1890. Revista Justiça \& História, v. 11, p. 89-124, 2011.

SONTAG, Ricardo. Código Criminológico? Ciência jurídica e codificação penal no Brasil (1888-1899). Rio de Janeiro: Editora Revan, 2014.

SOUZA, P. K. d. As competências estaduais na construção da república: fundamentos e contexto do código do processo civil e comercial do Rio Grande do Sul (1908). Dissertação (mestrado). Orientador: FLORES, A. d. J. D. M. Universidade Federal do Rio Grande do Sul. PPGD, Porto Alegre, BR-RS, 2015.

VALLE, Gabrielle Stricker do. Uma história da cultura jurídica processual penal brasileira (1930-1945) (Dissertação, Mestrado). Orientadora: Clara Maria Roman Borges; coorientador: Luís Fernando Lopes Pereira. Curitiba, 2018.

TEIXEIRA, Arley Fernandes. O perdão do ofendido na cultura jurídico-penal brasileira do século XIX: negociação no século da justiça pública?. Revista Brasileira de Direito Processual Penal, v. 5, n. 1, p. 299-338, 2019. https://doi.org/10.22197/ rbdpp.v5i1.213

VIANNA, Godofredo. Projecto de codigo do processo criminal do estado do maranhao. Maranhao: Impr Oficial, 1917.

WEBER, Max. Economy and society: An outline of interpretive sociology. Berkley: University of California Press, 1978. 


\section{Additional information and author's declarations (scientific integrity)}

Acknowledgement: este estudo foi financiado parcialmente pela Coordenação de Aperfeiçoamento de Pessoal de Nível Superior Brasil (CAPES) - Código financeiro 001. O autor agradece aos editores-associados Georges Martyn e Ricardo Sontag pelas observações e correções, bem como aos revisores anônimos pelas críticas e sugestões.

Conflict of interest declaration: the author confirms that there are no conflicts of interest in conducting this research and writing this article.

Declaration of authorship: all and only researchers who comply the authorship requirements of this article are listed as authors; all coauthors are fully responsible for this work in its entirety.

Declaration of originality: the author assures that the text here published has not been previously published in any other resource and that future republication will only take place with the express indication of the reference of this original publication; he also attests that there is no third party plagiarism or self-plagiarism.

\section{Editorial process dates}

(http://www.ibraspp.com.br/revista/index.php/RBDPP/about/editorialPolicies)

- Submission: 15/05/2021

- Desk review and plagiarism check: 01/06/2021

- Review 1: 23/06/2021

- Review 2: 29/06/2021

- Preliminary editorial decision: 30/06/2021

- Correction round return: 07/07/2021

- Final editorial decision: 09/07/2021
Editorial team

- Editor-in-chief: 1 (VGV)

- Associated-editor: 1 (RS e MG)

- Reviewers: 2 


\section{HOW TO CITE (ABNT BRAZIL):}

NODARI, Régis João. Ordem, liberdades e estadualização do processo penal na primeira república (1889-1930): João Mendes de Almeida Júnior processualista. Revista Brasileira de Direito Processual Penal, vol. 7, n. 2, p. 1141-1186, mai./ago. 2021.

https://doi.org/10.22197/rbdpp.v7i2.575 